\title{
Insights into Thermophilic Plant Biomass Hydrolysis from Caldicellulosiruptor Systems Biology
}

\author{
Sara E. Blumer-Schuette
}

Department of Biological Sciences, Oakland University, Rochester, MI 48309, USA; blumerschuette@oakland.edu

Received: 1 February 2020; Accepted: 7 March 2020; Published: 10 March 2020

\begin{abstract}
Plant polysaccharides continue to serve as a promising feedstock for bioproduct fermentation. However, the recalcitrant nature of plant biomass requires certain key enzymes, including cellobiohydrolases, for efficient solubilization of polysaccharides. Thermostable carbohydrate-active enzymes are sought for their stability and tolerance to other process parameters. Plant biomass degrading microbes found in biotopes like geothermally heated water sources, compost piles, and thermophilic digesters are a common source of thermostable enzymes. While traditional thermophilic enzyme discovery first focused on microbe isolation followed by functional characterization, metagenomic sequences are negating the initial need for species isolation. Here, we summarize the current state of knowledge about the extremely thermophilic genus Caldicellulosiruptor, including genomic and metagenomic analyses in addition to recent breakthroughs in enzymology and genetic manipulation of the genus. Ten years after completing the first Caldicellulosiruptor genome sequence, the tools required for systems biology of this non-model environmental microorganism are in place.
\end{abstract}

Keywords: Caldicellulosiruptor; extreme thermophile; genomics; thermostable enzymes; enzyme synergy; systems biology

\section{Introduction}

Over 50 years have passed since Thomas Brock's discovery that Yellowstone National Park's hot springs were teeming with microbial life [1]. In the half century after his seminal research, advances in DNA sequencing and molecular cloning techniques have hastened the discovery of enzymes from extreme to hyperthermophilic microorganisms. Heterotrophs that thrive at these elevated temperatures are of special interest for their robust and temperature-stable carbohydrate active enzymes (CAZymes) capable of deconstructing even the most recalcitrant parts of plant biomass [2,3]. Prior to the 1980s, moderate thermophiles, such as Hungateiclostridium thermocellum (formerly 'Clostridium thermocellum'), were isolated and described as being capable of rapidly degrading cellulose [4], followed by the discovery of macromolecular enzyme complexes known as cellulosomes [5,6]. The question remained, however, if microorganisms inhabiting terrestrial hot springs at higher temperature ranges were capable of degrading all carbohydrates in plant biomass similar to H. thermocellum. Reports of cellulolytic microbial isolates enriched from terrestrial hot spring samples grown above $70^{\circ} \mathrm{C}[7-10]$ raised the upper temperature limits for biological crystalline cellulose hydrolysis.

Bacterial lignocellulose deconstruction at elevated temperatures (above $70^{\circ} \mathrm{C}$ ) evolved to leverage specific carbohydrate active enzyme (CAZyme) families and carbohydrate binding modules (CBM) [3]. Enzymes capable of hydrolyzing glycosidic bonds within cellulose chains (endo-acting) have been characterized from hyperthermophilic microoganisms [11-13], however, cellobiohydrolase enzymes (exo-acting) have been identified in microorganisms growing optimally up to a temperature range of 70 to $80^{\circ} \mathrm{C}$, which appears to be the thermal limit for true cellulase activity. Possibilities for this observed phenomenon include the lack of crystalline cellulose in hyperthermophilic marine biotopes, or alternatively, that cellobiohydrolases evolved in the terrestrial extreme thermophiles and do not 
share a common ancestry with hyperthermophiles as a result. Evidence of horizontal gene transfer of primary cellulases between extreme and hyperthermophilic microbes has yet to be observed. Therefore, extremely thermophilic bacteria remain as the main source of the most thermostable primary cellulases on Earth.

\section{Maturation of Caldicellulosiruptor Genomics}

With the discovery of extremely thermophilic, plant biomass deconstructing genus Caldicellulosiruptor, the original focus was the function of modular, multi-functional enzymes that were cloned and sequenced (originally reviewed in [14]). However, the full diversity of the Caldicellulosiruptor enzymatic capacity was not fully appreciated until the first genome was published in 2008 [15]. Adding to the interest in this genus, an additional 40 genome sequencing projects involving the genus Caldicellulosiruptor were reported on the genomes online database [16], consisting of a total of 14 species. Since the release of the C. saccharolyticus genome in 2008 , the average annual number of peer reviewed publications on the genus Caldicellulosiruptor has increased roughly 13-fold. The availability of the genome sequences catalyzed a sharp increase in knowledge on the enzymology and physiology of this genus.

\subsection{Comparative Caldicellulosiruptor Genomics}

The initial comparison between Caldicellulosiruptor saccharolyticus and Caldicellulosiruptor bescii (formerly 'Anaerocellum thermophilum') identified that the glucan degradation locus (GDL) could vary in complexity between strongly cellulolytic species [17]. Based on earlier shotgun cloning efforts to identify genes located in the glucan degradation locus (GDL), it was already observed that C. bescii encoded for a number of cellulases and xylanases [18], and that at least one of these enzymes was a multifunctional, modular cellulase [19] that shared similarities to CelA encoded by C. saccharolyticus [20]. Overall, both C. saccharolyticus and C. bescii possess a high number of carbohydrate binding modules and glycoside hydrolases in their respective genomes when compared to other thermophiles, and over $86 \%$ of the open reading frames (ORFs) in their respective genomes were orthologs [17].

As expected, the Caldicellulosiruptor core genome has been reduced from 1543 open reading frames (ORFs) shared among eight species [21] to 1367 ORFs shared among 14 species [22]. In comparison, the high level of genetic diversity among the genus Caldicellulosiruptor led to an increase of the pangenome from 3493 ORFs (13 species) [23] to 3791 ORFs (14 species) [22]. The initial Caldicellulosiruptor pangenome was constructed from the genomes of eight strongly to weakly cellulolytic members of the genus Caldicellulosiruptor [24,25], and was analyzed along with proteomics data to identify key genes unique to the strongly cellulolytic members of the genus Caldicellulosiruptor, that would assumedly be crucial to their strongly cellulolytic lifestyle [21].

\subsubsection{Evolutionary Adaptations to a Strongly Cellulolytic Lifestyle}

While most species had been isolated and described as being cellulolytic (see Table 1) when tested for their ability to shred filter paper, some species did not degrade filter paper to any appreciable degree [21,25] and were excellent candidates for comparison to the strongly cellulolytic species. The presence of enzymes possessing a catalytic glycoside hydrolase (GH) family domain (including CelA) were determined to be a marker of cellulolytic capacity [21]. Ten of the 14 sequenced Caldicellulosiruptor genomes encode for enzymes containing at least one GH48 domain, with six of those species encoding for two (C. obsidiansis and C. changbaiensis) or three GH48 domains (C. bescii, C. danielii, C. kronotskyensis, C. morganii, and C. naganoensis) [21-23]. Regardless of the number of GH48 domains, most cellulolytic Caldicellulosiruptor species grow at similar rates on microcrystalline cellulose. However, their overall ability to solubilize biomass or crystalline cellulose varies, with $C$. bescii and $C$. morganensis outperforming other cellulolytic species $[22,23,26]$. 
Table 1. Sequenced members of the genus Caldicellulosiruptor.

\begin{tabular}{ccccccc}
\hline Species Name & $\begin{array}{c}\text { Genome } \\
\text { Size } \mathbf{( M b )}\end{array}$ & Total ORFs & GC\% & Year Sequenced & $\begin{array}{c}\text { Cellulolytic } \\
\text { Capacity }\end{array}$ & $\begin{array}{c}\text { Genome } \\
\text { Reference }\end{array}$ \\
\hline C. acetigenus & 2.59 & 2498 & 36.1 & 2013 & Weak & {$[23]^{\text {a }}$} \\
C. bescii & 2.96 & 2905 & 35.2 & $2018^{\text {a }}$ & Strong & {$[17]$} \\
C. changbaiensis & 2.91 & 2532 & 35.1 & 2019 & Strong & {$[22]$} \\
C. danielii & 2.83 & 2731 & 35.8 & 2014 & Strong & {$[23]$} \\
C. sp. F32 & 2.38 & 2487 & 35.2 & 2013 & Strong & {$[27]$} \\
C. hydrothermalis & 2.77 & 2685 & 36.1 & 2011 & Weak & {$[21]$} \\
C. kristjanssonii & 2.8 & 2707 & 36.1 & 2011 & Weak & {$[21]$} \\
C. kronotskyensis & 2.84 & 2642 & 35.1 & 2011 & Strong & {$[21]$} \\
C. lactoaceticus & 2.67 & 2549 & 36.1 & 2011 & Moderate & {$[21]$} \\
C. morganii & 2.49 & 2407 & 36.5 & 2014 & Strong & {$[23]$} \\
C. naganoensis & 2.51 & 2436 & 35.4 & 2014 & Strong & {$[23]$} \\
C. obsidiansis & 2.53 & 2389 & 35.2 & 2011 & Strong & {$[24]$} \\
C. owensensis & 2.43 & 2322 & 35.4 & 2011 & Weak & {$[21]$} \\
C. saccharolyticus & 2.97 & 2834 & 35.3 & 2007 & Moderate & {$[15]$} \\
\hline
\end{tabular}

a The publicly available genome for C. acetigenus was analyzed as a part of this study.

This variability in enzymatic capacity may be related to the functional role each species plays during plant biomass degradation in situ. Accordingly, in a physiological comparison between two highly (C. bescii, C. kronotskyensis) and one moderately cellulolytic species (C. saccharolyticus), C. saccharolyticus was observed to more efficiently ferment the limited amount of soluble sugars released by its enzymes in comparison to the highly cellulolytic Caldicellulosiruptor species [26]. Furthermore, the total number of CAZymes does not correlate with cellulolytic ability, as the highly cellulolytic $C$. kronotskyensis and weakly cellulolytic $C$. hydrothermalis have the highest and second highest number of glycoside hydrolase (GH) domains [21]. Most of the observed diversity in GH domains is due to non-GDL genes, although new combinations of GH domains in GDL-encoded modular enzymes were noted for C. morganii, C. danielii, and C. naganoensis [23].

With the availability of genome sequences, custom oligonucleotide microarray chips were designed for C. saccharolyticus [15], C. bescii [17], and C. kronotskyensis [26]. Most studies focused on comparisons of global transcriptomes in response to various monosaccharide sugars [15,28], plant related polysaccharides [17,28,29], and plant biomass [26,29]. Despite their common ability to solubilize plant biomass, differences in the regulation of CAZymes, motility-related genes, and ABC transporters have been observed among the highly cellulolytic C. bescii, C. kronotskyensis, and moderately cellulolytic C. saccharolyticus [26] and in a proteomic comparison between C. bescii and C. obsidiansis [30]. Together, these studies imply that within Caldicellulosiruptor communities, even species producing powerful cellulases may specialize within their community. C. bescii and C. kronotskyensis, for example, were both isolated from the Kamchatka, Russia region [10,31], and C. saccharolyticus was isolated from the Taupo region of New Zealand, along with other phenotypically different members of the same genus [32].

\subsubsection{Diverse Mechanisms Used to Maintain Cell-Substrate Proximity}

Aside from using comparative genomics to determine the cellulolytic capacity of the genus Caldicellulosiruptor, each species was found to differ in the number of genes encoding for proteins and enzymes involved in the attachment to lignocellulosic substrates. Proteins with S-layer homology (SLH) domains are one such class and are required for the interface between cellulosomes and cells in the Clostridiales [33]. However, in the non-cellulosomal genus Caldicellulosiruptor, each species sequenced possesses multiple S-layer located enzymes and proteins (between 10 and 19) [34]. Interestingly, the number of genes encoding for S-layer located proteins does not correlate with cellulolytic capacity [21], including the distribution of S-layer enzymes [34]. One S-layer located enzyme is a part of the Caldicellulosiruptor core-genome (GH5-CBM28-SLH-SLH-SLH) [21,34] and was proposed 
to function as an enzyme and, additionally, to promote adherence to cellulose [35]. Latter studies identified that other S-layer proteins unique to various Caldicellulosiruptor species were also involved in the attachment to cellulose and pectin [35] or xylan [34].

Lastly, high-temperature cellulose adhesins (tāpirins) were identified through comparative genomics and proteomics efforts [21,36]. Genes encoding for uncharacterized hypothetical proteins, later identified as tāpirins, are located directly upstream of the GDL, and were initially demonstrated to have micromolar affinity for microcrystalline cellulose along with an unusual $\beta$-helix shape [36]. Two additional tāpirin structures were recently solved from divergent tāpirins produced by weakly cellulolytic species (C. hydrothermalis and C. kristjanssonii) that share a similar shape to the highly cellulolytic tāpirin proteins [37]. Furthermore, biophysical analysis of tāpirins from weakly cellulolytic species indicates that these tāpirins bind to more sites on cellulose, likely aided by a longer predicted binding pocket in their structure [36,37], and grant a competitive advantage to adhere to plant biomass in their environment. Not all strongly cellulolytic members of the genus Caldicellulosiruptor use classical tāpirins to adhere to cellulose, as atypical tāpirin proteins similar to those encoded for by $C$. owensensis and $C$. acetigenus were identified in the genome of $C$. changbaiensis [22]. Additional biophysical analysis of these atypical tāpirins is required, as they may represent a unique mechanism of cellulose adherence used by this genus.

\subsection{Caldicellulosiruptor Community Analyses}

The goal of enriching extremely thermophilic cellulolytic microorganisms was to ultimately identify thermostable enzymes from those organisms. Prior to the isolation of individual species, communities of cellulolytic microbes from geothermally heated springs were enriched on cellulose $[7,9,38,39]$ for initial biochemical and phylogenetic analysis. At that time, New Zealand was the site of the most extensive phylogenetic characterization of Caldicellulosiruptor strains [32]. However, due to the amplicon length constraints of Sanger sequencing, initial CAZymes identified from the genus Caldicellulosiruptor were identified from isolated species, such as C. bescii [19] and C. saccharolyticus [20,40-42], rather than from cellulolytic communities. Development of primer pairs specific for conserved regions of $16 \mathrm{~S}$ rRNA genes (reviewed in [43]) allowed for culture-independent insights into the global presence of the genus Caldicellulosiruptor (see Figure 1). Furthermore, the ability of the genus Caldicellulosiruptor to hydrolyze plant biomass or other recalcitrant polysaccharides and produce acetate and hydrogen at elevated temperatures [44-47] has led to the identification of environmental strains in fermenters and digesters inoculated with environmental samples.

The availability of genome sequences has bolstered Caldicellulosiruptor species identification from hot springs microbial community analyses from the Azores [48], Iceland [49], Russia [50], Tunisia [51], and the United States [23,52] (see Table 2). While Caldicellulosiruptor species were isolated from most sites sampled, the only report of Caldicellulosiruptor from the African continent was a single 16S rRNA gene clone identified from a hot spring in Tunisia, which was predominantly colonized by Firmicutes [51]. Based on culture-independent $16 \mathrm{~S}$ rRNA gene amplification and metagenome sequencing, the genus Caldicellulosiruptor, along with genera Fervidobacterium, Dictyoglomus, and Sulfurihydrogenibium were most abundant in a slightly alkaline, highly reduced solfatara effluent stream in the Azores [48]. The genera Caldicellulosiruptor, Fervidobacterium, and Dictyoglomus were also detected by 16S rRNA gene clones isolated from separate enrichment cultures sampled from springs in the Uzon Caldera, Kamchatka, Russia [50]. Obsidian Pool in Yellowstone National Park in the United States has been extensively sampled, including two high-temperature enrichment studies focused on plant-biomass degrading heterotrophs $[23,52]$. In both studies, the genus Caldicellulosiruptor predominated enrichment cultures between 70 and $75^{\circ} \mathrm{C}$ [23,52]. Community analysis also identified Caldicellulosiruptor species in extremely thermophilic hydrogen- or methane-producing consortia that were sourced from the Ta $\mathrm{Na}$ Ma Rao hot spring in Thailand [53]. One study also yielded a novel $\beta$-galactosidase enzyme cloned from an uncultured Caldicellulosiruptor species present in a hot spring from Yongtai, China, that was identified through $16 \mathrm{~S}$ rDNA phylogeny [54]. Overall, cellulose enrichment cultures 
from multiple continents grown above $70{ }^{\circ} \mathrm{C}$ were composed predominantly of members from the genus Caldicellulosiruptor, supporting their primary role in cellulose hydrolysis at elevated temperatures. Interestingly, geothermally heated springs are not the only potential sources of isolated Caldicellulosiruptor species, for example, C. owensensis was isolated from solar heated mud flats in Owens Lake, CA [55], and C. sp. F32 was isolated from a compost enrichment in China [56]. Caldicellulosiruptor spp. most similar to C. kristjanssonii based on 16S rDNA analysis were identified from manure-supplemented distillery waste streams [57], although it is unclear if the Caldicellulosiruptor cells came from the distillery wastewater or the digested cow manure. Additional reports of Caldicellulosiruptor species identified from animal microbiota included community analyses of a rumen microbial community [58], and poultry caecum community [59] opening up the exciting prospect of mesophilic relatives of the Caldicellulosiruptor ("Mesocellulosiruptor"), similar to the discovery of mesophilic members of the phylum Thermotogae (reviewed in [60]). Caldicellulosiruptor species were also detected in the latter stages of a human waste-amended thermophilic aerobic digestor in Japan [61], and by community analysis from anaerobic digesters present in France [62], India [63], China [64], and Hungary [65]. The anaerobic digester in Hungary was run at mesophilic temperatures, and was initially inoculated with pig manure, further supporting the existence of mesophilic Caldicellulosiruptor as part of animal gut microbiomes. Finally, other studies on fermenters inoculated with soil from Germany [66], and a hydrogen-generating bioreactor in the Netherlands with unknown inoculum [67] also identified different Caldicellulosiruptor species than those used in the inoculum, C. saccharolyticus. Further lines of evidence supporting the existence of "Mesocellulosiruptor" include a recent survey of soil microorganisms in Spain that identified Caldicellulosiruptor species as minor members of the soil community [68]. Of all the reports of Caldicellulosiruptor species, the most unusual may be of the identification of a C. lactoaceticus 16S rRNA gene clone from drilling fluid sampled roughly $2.5 \mathrm{~km}$ below the Earth's surface [69]. Due to the multiple examples of Caldicellulosiruptor 16S rRNA genes being identified in bioreactors, animal manure, and soil, biotopes, aside from geothermally heated springs, appear to harbor Caldicellulosiruptor species, or relatives of the genus ("Mesocellulosiruptor") that may also possess robust enzymes of interest.

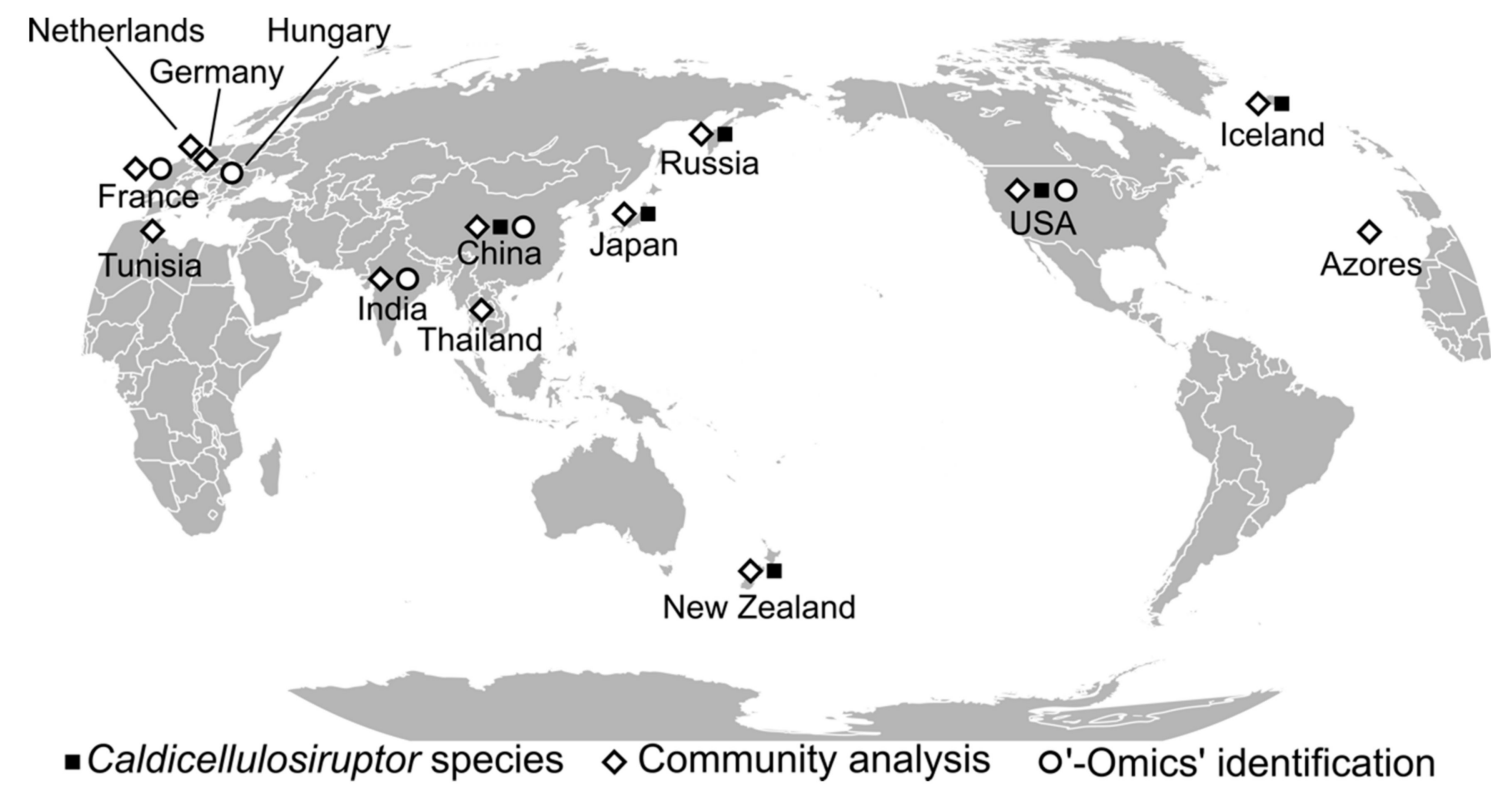

Figure 1. Global sites where members of the genus Caldicellulosiruptor have been isolated or detected. Locations are approximate to country or territory from peer-reviewed literature (see Table 2). Open diamonds, 16S rRNA gene sequencing; open circles, meta-omics identification; closed squares, Caldicellulosiruptor spp. genomic sequencing. 
Table 2. Published Caldicellulosiruptor metagenomics or community analysis.

\begin{tabular}{|c|c|c|c|c|}
\hline Country & Analysis & $\begin{array}{c}\text { Origin } \\
\text { Temperature }\end{array}$ & Source & Ref. \\
\hline Azores & community analysis & Thermophilic & Geothermally heated springs & [48] \\
\hline China & community analysis & Thermophilic & Anaerobic digester sludge & [64] \\
\hline China & community analysis & Thermophilic & Drilling fluid & [69] \\
\hline China & community analysis & Thermophilic & Geothermally heated spring & [54] \\
\hline China & community analysis & Mesophilic & Unknown & [57] \\
\hline France & $\begin{array}{l}\text { metaproteomics, } \\
\text { community analysis }\end{array}$ & Thermophilic & $\begin{array}{l}\text { Anaerobic digester sludge, } \\
\text { municipal solid waste }\end{array}$ & [62] \\
\hline Germany & community analysis & Mesophilic & soil or compost & {$[66]$} \\
\hline Hungary & metagenomics & Mesophilic & Pig manure & [65] \\
\hline Iceland & $\begin{array}{l}\text { cellulose or xylan } \\
\text { enrichments }\end{array}$ & Thermophilic & Geothermally heated springs & [49] \\
\hline India & $\begin{array}{l}\text { metagenomic } \\
\text { sequencing } \\
\text { metagenomic }\end{array}$ & Unknown & Anaerobic digester sludge & [63] \\
\hline India & $\begin{array}{c}\text { and metatranscriptomic } \\
\text { sequencing }\end{array}$ & Mesophilic & Gir cattle rumen & {$[58]$} \\
\hline India & community analysis & Mesophilic & Poultry caecum & [59] \\
\hline Japan & community analysis & Thermophilic & $\begin{array}{l}\text { Thermophilic aerobic } \\
\text { digester, human waste }\end{array}$ & {$[61]$} \\
\hline Japan & community analysis & Thermophilic & Geothermally heated spring & {$[70]$} \\
\hline Japan & community analysis & Mesophilic & $\begin{array}{l}\text { Anaerobic sludge (upflow } \\
\text { anaerobic sludge blanket) }\end{array}$ & [71] \\
\hline Netherlands & community analysis & Thermophilic & Unknown & [67] \\
\hline Thailand & community analysis & Thermophilic & Geothermally heated springs & [53] \\
\hline Tunisia & community analysis & Thermophilic & Geothermally heated springs & [51] \\
\hline United States & $\begin{array}{l}\text { community analysis } \\
\text { metagenomic }\end{array}$ & Thermophilic & Geothermally heated spring & [52] \\
\hline United States & $\begin{array}{l}\text { sequencing, community } \\
\text { analysis }\end{array}$ & Thermophilic & Geothermally heated spring & [23] \\
\hline
\end{tabular}

\subsection{Caldicellulosiruptor Meta(proteo-)genomics}

With rapid advancements in next generation sequencing and proteomics, an assembly of partial genomes or identification of active metabolic pathways from environmental Caldicellulosiruptor isolates present in microbial communities is possible. Interestingly, the initial studies using next generation '-omics' techniques that identified Caldicellulosiruptor species as predominant members of microbial communities started from anaerobic digestion sludge [62,65]. For example, Caldicellulosiruptor spp. were identified through metaproteomics as one of the predominant bacteria involved in polysaccharide hydrolysis in a cellulolytic microcosm that was initially inoculated with anaerobic digester sludge [62]. Analysis of whole cell protein fractions identified peptides corresponding to the predominant Caldicellulosiruptor cellulase, CelA, along with CAZymes, more commonly associated as being intracellular [62]. It is not surprising that few extracellular Caldicellulosiruptor enzymes were identified in this study since neither the supernatant nor substrate were sampled for peptide identification. Other proteomic efforts on the genus Caldicellulosiruptor have highlighted the differences in the peptide profiles of whole cell versus supernatant $[30,72]$ or between whole cell, supernatant, and substrate-bound samples [21].

In addition to the identification of hydrolytic enzymes from anaerobic digestor metaproteomics, metagenomes were sequenced from enriched cellulolytic communities harvested from Obsidian Pool, Yellowstone National Park in the United States [23]. While a sole Caldicellulosiruptor species was previously isolated from Obsidian Pool (C. obsidiansis), other global sites, New Zealand, for example, host a diverse community of Caldicellulosiruptor species [73]. Cellulolytic communities, enriched in situ or from water samples, were sequenced to assess the diversity of Caldicellulosiruptor 
species in other hot spring environments. Initial community analysis of these cellulose-enriched communities determined that members of the Caldicellulosiruptor genus ranged from $89.9 \%$ to $38.7 \%$ of the total community population, although the relative abundance of Caldicellulosiruptor species only marginally correlated with solubilization of lignocellulose [23], emphasizing the role of other non-cellulolytic members of these microbial communities. Incomplete Caldicellulosiruptor genomes assembled from metagenomes shared a high degree of homology and synteny with the $C$. obsidiansis genome. Regardless, key differences were noted in their GDL composition, including the presence of an additional modular cellulase (GH10-CBM3-CBM3-GH48) in two of the enrichments that C. obsidiansis lacks [23]. These communities were enriched on microcrystalline cellulose prior to metagenomic sequencing, which may have resulted in an overrepresentation of the strongly cellulolytic Caldicellulosiruptor strains, considering that half of the communities enriched encoded for the three-key synergistic cellulases, CelA (GH9-CBM3-CBM3-CBM3-GH48), CelC (GH10-CBM3-CBM3-GH48), and CelE (GH9-CBM3-CBM3-CBM3-GH5) [74].

\section{Modular Caldicellulosiruptor CAZymes}

Every strongly cellulolytic member of the genus Caldicellulosiruptor that has been genome sequenced encode for a locus of modular, multifunctional enzymes. This genomic region, named the glucan degradation locus (GDL), contains one or more enzymes that possess the marker for the highly cellulolytic phenotype, GH 48 [21,25]. Historically, cellulases from the genus Caldicellulosiruptor were under considerable focus, and the first report of large ( $>180 \mathrm{kDa})$ glycosylated cellulases was noted from C. naganoensis (formerly 'Thermoanaerobacter cellulolyticus') [75]. The modular architecture of enzymes encoded by the GDL was first reported after sequencing a genome library clone that encoded for celB (GH10-CBM3-GH5) from C. saccharolyticus [76], which was then rapidly followed by the cloning and characterization of other modular enzymes from C. saccharolyticus [41,42]. Initially, the identification of modular enzymes encoded by the GDL or xylan degradation locus (XDL) was facilitated by sequencing lambda phage genomic libraries constructed from Caldicellulosiruptor sp. Tok7B.1 [14,77] or C. saccharolyticus [20,78].

Now, with the benefit of comparative genomics including 14 Caldicellulosiruptor genomes, and one metagenome assembled genome [21-23], the diversity of GH architecture in the GDL is well characterized, and the minimal complement of cellulases required for cellulose or lignocellulose hydrolysis has been identified [74,79]. From newly available genome sequences, modular enzymes present in the GDL were identified with new combinations of catalytic domains or additional CBM3 modules in established modular enzymes, such as the case with C. morganii [23]. The enzymatic significance of these changes still needs to be characterized, although enzymes with the same modular structure, CelA, for example, have different activities, with CelA from C. bescii outperforming CelA from C. danielii [23]. Considering that only CelA from C. saccharolyticus [20], C. bescii [19,80,81], and now C. danielii have been characterized, it remains to be seen if there is a superior candidate to $C b C e l A$. As individual enzymes from various Caldicellulosiruptor species have been cloned, each research group has used differing gene naming conventions. In this review, the naming convention for the GDL in C. bescii will follow unless noted.

\subsection{CelA}

While heterologous expression in Escherichia coli is commonplace for the initial characterization of recombinant enzymes, the size of the modular cellulases may be a limiting factor for the adoption of these cellulases in other systems. The largest Caldicellulosiruptor modular enzyme, CelA (GH9-CBM3-CBM3-CBM3-GH48), was initially identified from screening a C. saccharolyticus genome library for activity on amorphous cellulose, and was subsequently sequenced [20]. However, hydrolysis of crystalline cellulose was not observed until natively purified CelA was characterized from C. bescii [19]. Furthermore, observation of CelA-treated microcrystalline cellulose particles highlighted this enzyme's unique mechanism of tunneling through cellulose fibers during hydrolysis, in addition to 
the more commonly observed chewing back mechanism that other commercial cellulases display [81]. Both catalytic domains of CelA likely coordinate efficient hydrolysis through intramolecular synergy (GH9, endoglucanase, and GH48, cellobiohydrolase) as demonstrated by the intermolecular synergy of single GH truncations during hydrolysis of microcrystalline cellulose [80]. While CelA is capable of outperforming commercial fungal cellulase mixtures [81] and can hydrolyze highly crystalline cellulose, it will adsorb to lignin, rendering the enzyme ineffective [82]. Interestingly, C. bescii was observed to solubilize all components of plant biomass, lignin included, during growth on switchgrass, which could alleviate CelA inhibition by lignin adsorption [83]. However, this phenomenon is likely dependent on the plant species, as C. bescii was unable to solubilize lignin present in poplar [84].

Contribution of CelA to cellulose hydrolysis was also demonstrated by a C. bescii celA knockout mutant, which was reduced in its ability to grow on cellulose and overall cellulase activity when induced by cellobiose [85]. In contrast, deletion of celA in a genetically stable C. bescii parental strain [86] only resulted in a reduction in cellulolytic ability by 45\% [74]. One explanation for this discrepancy is misassembled regions in the original C. bescii genome (NCBI accession NC_012034.1) [86] used to design the original CelA knockout vector in Young et al. [85]. These assembly errors in the GDL are not entirely unexpected, as there are multiple repeating nucleotide sequences present in the GDL particularly those encoding for carbohydrate binding modules and GH family 48 and 5 domains [74]. Primers designed for the initial celA knockout vector will amplify a $1 \mathrm{~kb}$ downstream sequence that is present in multiple regions and could result in the deletion of an additional two GDL genes (celB, and $c e l C)$. Expansion and diversity of the Caldicellulosiruptor GDL has been proposed to occur through gene recombination after duplication [14,77] and would explain the presence of these repeated regions in the GDL. This deletion strain is still useful for the in vitro analysis of CelA enzyme engineering, however, and directed mutations of native C. bescii celA, by insertion of N-terminal aspartate repeats, improved glucose release by the extracellular protein fraction [87] and improved growth on cellulose as monitored by plate counting [85].

Recent characterization of full length and truncated CelA has used natively purified enzyme [81], native overexpression [74,79,88,89], and heterologous expression in E. coli or Bacillus megaterium [80], where the results from homologously versus heterologously produced CelA may not be comparable, due to differences in post-translational modifications, such as glycosylation. Linker regions present in modular enzymes are rich in proline-threonine repeats that indicate that CelA is likely glycosylated, and one report on the native purification of CelA indicated that the purified protein stained positively for glycosylation [19]. Glycosylation of CelA with galactose disaccharides was confirmed by overexpression in the C. bescii $\triangle$ celA strain $[89,90]$, only extracellular CelA was observed as being glycosylated [89] and the glycotransferase (GT) located in the GDL is required for CelA glycosylation [79,91]. Initially, deletion of the GT responsible for glycosylation of CelA resulted in proteolytic clipping of extracellular enzymes and lower cell densities observed by plate counts from planktonic cells growing on microcrystalline cellulose [91]. In contrast, deletion of the same GT from a different parental C. bescii strain did not result in a dramatic effect, and the GT deletion strain was still capable of solubilizing microcrystalline cellulose [79]. Glycosylation of CelA does have a protective effect against proteases, and full length glycosylated CelA hydrolyzed 22\% more microcrystalline cellulose in vitro versus non-glycosylated CelA [90]. In contrast, Conway et al. monitored cellulose solubilization in vivo, and other factors aside from glycosylation may impact enzyme efficiency [79]. Lastly, while fewer C. bescii GT knock out colonies were observed by Russell et al., [91], no comparison in growth on a solid medium was made between planktonic cells grown on cellobiose versus cellulose. It is possible that in addition to reduced stability of extracellular hydrolytic enzymes, the glycosylation deficient $C$. bescii strains are also deficient in their ability to form colonies on solid medium, resulting in a false negative result for growth on microcrystalline cellulose. 


\subsection{Modular Cellulase Synergy}

In addition to the synergy between catalytic domains in the modular cellulases, it would be expected that the enzymes themselves work in concert to hydrolyze plant biomass. Synergism between heterologously produced (E. coli) truncations of CelB ( ${ }^{*}$-CBM3-CBM3-GH44), with CelE (GH9-CBM3-CBM3-CBM3-*), CelD ( $\left.{ }^{*}-\mathrm{CBM} 3-\mathrm{CBM} 3-\mathrm{CBM} 3-\mathrm{GH} 5\right)$, or the S-layer located cellulase (GH5-CBM28-*) was detected [92]. Interestingly, the combination of truncated CelE with CelD was only additive in activity, while homologously produced full-length CelE and CelD synergistically hydrolyzed microcrystalline cellulose [79]. When full-length modular cellulases from the GDL were tested for synergistic activity, most combinations were found to be positive, highlighting the need for homologously produced full length enzymes. The combination of CelA, CelC (GH10-CBM3-CBM3-GH48), and CelE was most optimal (degree of synergy, 3.8) on a glucan conversion basis when compared to mixtures of CelA plus three or more additional enzymes from the GDL [79]. In contrast, when monitoring the activity of the GDL enzymes in vivo, the deletion of CelA, CelB, and CelC was sufficient to reduce cellulose solubilization by over $90 \%$ [74]. Regardless of the activity of cell-free cellulase enzyme mixtures, the highest levels of cellulose solubilization were observed when C. bescii cells are present [79], supporting past findings in other systems that cell-substrate proximity also plays a role in efficient cellulose hydrolysis [93]. Four additional combinations of catalytic domains in the GDL were identified from the genome sequencing of $C$. danielii, $C$. morganii, and C. naganoensis, including two enzymes that include three catalytic domains (GH12-Gh5-CBM3 × 3-GH48 and GH10-CBM3-GH12-GH48) [23]. Homologous production of full length, glycosylated versions of these enzymes noted that these enzymes, like others encoded by the $C$. bescii GDL, hydrolyze microcrystalline cellulose synergistically [94] and are candidates for engineering a superior $C$. bescii biocatalyst.

\subsection{Xylanases}

In addition to the GDL, six isolated species, C. acetigenus, C. bescii, C. changbaiensis, C. kronotskyensis, C. owensensis, and C. saccharolyticus encode for a second locus of modular enzymes capable of hemicellulose hydrolysis [21]. While not as extensively studied, synergy exists between the main xylanases and side-chain cleaving enzymes from C. bescii [95]. Other, less cellulolytic Caldicellulosiruptor species may be superior sources of xylanases that will work synergistically with cellulases, since they have evolved to specialize on the other carbohydrate components of plant biomass. One example are the extracellular enzymes from weakly cellulolytic $C$. owensensis, which significantly increased the amount of sugar released from non-pretreated, high-hemicellulose plant biomass when used sequentially with commercial cellulase mixtures [96]. The exact polysaccharide composition of xylan can change between plant species, and more than one type of xylanase may be required to efficiently hydrolyze this heterogenous polysaccharide. An S-layer localized GH10 xylanase cloned from C. lactoaceticus was noted for five-fold higher activity on oat spelt xylan in comparison to birchwood or sugar case xylan [97]. It is foreseeable that future engineering efforts of $C$. bescii may be the inclusion of additional xylanases and other hemicellulose hydrolyzing enzymes from the more xylanolytic members of the genus, or other species, for example, Acidothermus cellulolyticus. Overexpression of two different xylanases from $A$. celluloyticus resulted in a significant improvement of $C$. bescii growth on birchwood xylan and sugar release from oat spelt or birchwood xylan [98], which were far larger gains than observed from a chromosomal knock-in of a C. kronotskyensis S-layer located xylanase in C. bescii [34].

\subsection{Heterologous Expression of Caldicellulosiruptor Enzymes in Other Systems}

Other thermophilic genera also serve as promising consolidated bioprocessing platforms, like $H$. thermocellum which is notable for its cellulosomes (reviewed in [99]) and cellulolytic efficiency [100], but is subject to feedback inhibition by cellobiose [101]. Prior studies have relieved this feedback inhibition in vitro by exogenous mixing of purified cellulosomes and chimeric 
native $\beta$-glucosidases with cohesion domains [101], or with other thermophilic $\beta$-glucosidases [102]. Since the genus Caldicellulosiruptor is extremely thermophilic, their enzymes, in theory, should prove to be stable when heterologously expressed in a system like $H$. thermocellum. Recently, a $\beta$-glucosidase from Caldicellulosiruptor sp. F32 was produced heterologously in $H$. thermocellum as a fusion to the cellulosomal cellobiohydrolase, CelS [103] where it increased cellulose hydrolysis best when expressed as a chromosomal knock-in rather than from a replicating plasmid. Interestingly, in a follow-up study, when the same $\beta$-glucosidase was fused to a cohesin type II domain and incorporated into the cellulosome, it continued to act synergistically in the hydrolysis of microcrystalline cellulose, and hydrolyzed wheat straw at better rates than non-supplemented cultures [104]. However, when crystallinity of the remaining cellulose was used as a measure of cellulase efficiency, a negative effect of cellulosomal $\beta$-glucosidase on hydrolysis was noted [104]. This is in contrast to a synthetic cellulosome constructed from recombinant enzymes and scaffoldin which incorporated a $C$. saccharolyticus $\beta$-glucosidase [105]. In this case, the $\beta$-glucosidase was fused to a dockerin domain similar to native cellulosomal enzymes, and a synergistic effect during corn stover hydrolysis was observed between the $\beta$-glucosidase from $C$. saccharolyticus and endo-cellulase and xylanases from thermophilic Geobacillus strains [105]. More recently, a designer cellulosome was constructed from all C. bescii catalytic domains, GH9 and GH48 from CelA, and GH5 from the core S-layer endoglucanase that outperformed ( $>1.5$-fold sugar release) the native $H$. thermocellum cellulosome during extended cellulose hydrolysis times at $75^{\circ} \mathrm{C}$ [106], demonstrating proof of concept for hyperthermophilic cellulosomes.

In addition to heterologous expression in other Firmicutes, Caldicellulosiruptor modular cellulases, CelA (Csac_1076) and CelB (GH10-CBM3-GH5, Csac_1078), from C. saccharolyticus were introduced and expressed in Thermotoga sp. RQ2 [107], which resulted in a modest increase in detectable endoglucanase activity. A truncated form of 'celB' from C. saccharolyticus (*-CBM3-GH5) was included in an ionic liquid (IL)-tolerant enzyme cocktail (JTherm) for concurrent saccharification and IL treatment, which released over three times more sugars from IL-pretreated biomass at elevated temperatures [108]. The same CelB truncation was heterologously expressed in the fungus, Aspergillus niger, and was again able to retain a high level of activity in comparison to other bacterial EGs expressed [109]. This is not surprising as two unidentified EG clones from a C. naganoensis genomic library [110,111] were also heterologously expressed in the fungus Saccharomyces cerevisiae [112,113] and released more sugars than the comparable clones expressed in E. coli.

\section{Caldicellulosiruptor Genetic Engineering}

In parallel with the intense enzymatic focus on the genus Caldicellulosiruptor, the development of genetic tools afforded the opportunity to develop C. bescii as a potential platform organism for consolidated bioprocessing (CBP) where the same organism would enzymatically attack and ferment plant biomass to usable products (CBP reviewed in [114,115]). Development of the Caldicellulosiruptor genetic system relied on the identification of restriction-modification systems [116] that were impeding transformation by improperly methylated DNA isolated from E. coli [116,117]. Genetic systems for C. bescii now include a pyrF-based counter selection method $[118,119]$ or kanamycin selection based on a highly thermostable resistance gene [120] together with a genetically tractable strain of $C$. bescii that experiences less mobile element genome rearrangements [86]. Reverse genetics using the pyrF-based counter selection method initially demonstrated the impact of CelA [85] and a downstream pectinase cluster [121] on the ability of $C$. bescii to grow on plant polysaccharides. In addition to the development of reverse genetics systems, an $E$. coli-C. bescii shuttle vector was constructed using the origin of replication from pBAS2 [122], one of the two native $C$. bescii plasmids [123]. Aside from being used for protein overexpression in $C$. bescii, this shuttle vector was also successfully maintained by $H$. thermocellum [124], expanding genetic tools for other thermophilic Firmicutes. 


\subsection{Metabolic Engineering}

There is a large body of work investigating anaerobic hydrogenesis by the genus Caldicellulosiruptor (reviewed in [125]), including intriguing recent findings of diauxic-like hydrogen productivity during co-fermentation of $\mathrm{C}_{5}$ and $\mathrm{C}_{6}$ sugars [126]. Conversion of plant biomass hydrolysates to hydrogen by C. saccharolyticus were previously demonstrated [47], and recent sequential co-cultures of Caldicellulosiruptor species coupled with mesophilic chemoorganotrophs [127] or chemolithotrophs [128] converting the Caldicellulosiruptor fermentation products to value added chemicals like polyhydroxybutyrate.

Hydrogenesis also represents an attractive pathway to engineer in C. bescii for either increased productivity or redirection of reducing equivalents to other valuable metabolic pathways. Accordingly, the initial genetic manipulations of $C$. bescii were conducted with the goal of developing $C$. bescii as a suitable platform organism for biofuel production. Deletion of the lactate dehydrogenase gene $(l d h)$ redirected reducing equivalents from the reduction of pyruvate to lactate to hydrogenases, which increased hydrogen gas production [119]. Furthermore, by introducing a replicating vector heterologously expressing an alcohol dehydrogenase gene (adhE) from $H$. thermocellum, C. bescii produced ethanol when grown on switchgrass with no exogenously added CAZymes [121]. This was a significant step, demonstrating that $C$. bescii was capable of second generation consolidated bioprocessing, where no physiochemical pretreatment of the plant biomass was required for fermentation. Further improvements in ethanol titers during the growth on cellulose or xylan were made by introducing a reduced ferredoxin NAD oxidoreductase complex (Rnf) from Thermoanaerobacter sp. X514 [129] into C. bescii, which increased the $\mathrm{NADH} / \mathrm{NAD}^{+}$ratio [130].

Since the optimal growth temperature of C. bescii $\left(\mathrm{T}_{\text {opt }} 78-80^{\circ} \mathrm{C}\right)$ [131] is higher than that of $H$. thermocellum $\left(\mathrm{T}_{\mathrm{opt}} 60^{\circ} \mathrm{C}\right.$ ) [4], a bi-functional $\mathrm{ADH}$ was engineered into $\mathrm{C}$. bescii from Thermoanaerobacter pseudethanolicus $\left(\mathrm{T}_{\mathrm{opt}} 65^{\circ} \mathrm{C}\right)$, which would likely perform better at the elevated growth temperatures used for C. bescii [132]. T. pseudethanolicus encodes for two bi-functional alcohol dehydrogenases, and between the two enzymes, $C$. bescii produced a higher titer of ethanol when expressing the NADH-dependent T. pseudethanolicus ADH during growth on microcrystalline cellulose or plant biomass [133]. However, the titers were almost 10-fold lower than those observed using the $H$. thermocellum ADH [121]. Another T. pseudethanolicus ADH, annotated as a butanol dehydrogenase, increased the tolerance of $C$. bescii to furfurals, a byproduct of thermal and acid-pretreatment of plant biomass, by reducing furfurals to their cognate alcohols which are less toxic [134].

\subsection{Heterologous Expression of CAZymes}

Aside from metabolic engineering, there also has been a great deal of interest in supplementing the CAZyme repertoire of $C$. bescii with additional, synergistic enzymes. Initially, modular Caldicellulosiruptor $\beta$-glucosidases were introduced in $H$. thermocellum to relieve cellobiose inhibition of cellulases [103-105], and in turn, two different enzymes, a $\beta$-glucosidase from $A$. cellulolyticus [135] and cellobiose phosphorylase [136], were produced in C. bescii, which increased the efficiency of cellulose hydrolysis. An important first step in increasing cellulolytic activity in $C$. bescii was demonstrated by chromosomal expression of a $\beta$-glucanase and/or endoglucanse from $A$. cellulolyticus, which resulted in synergistic increases in cellulose hydrolysis, and over a 17-fold improvement of $C$. bescii growth on cellulose [137]. Heterologous expression of a cellobiose phosphorylase from Thermotoga maritima to relieve cellobiose inhibition improved the performance of the $C$. bescii endoglucanase knock-in strain [91], and the best gains in cellulolytic capacity were observed when all three enzymes ( $\beta$-glucanase, endoglucanse, and cellobiose phosphorylase) were co-expressed in C. bescii [138]. Clearly, even though the GDL of $C$. bescii had evolved to maximize synergy between the endogenous $C$. bescii enzymes, there are opportunities to engineer superior cellulolytic strains. Improvements in xylan solubilization were also noted for $C$. bescii xylanase knock-in strains. As described above, expression of multiple GH10 enzymes from A. cellulolyticus [98] or an S-layer located xylanase from C. kronotskyensis (Calkro_0402) 
in C. bescii increased xylan hydrolysis in both cases and increased xylan attachment by the C. bescii (Calkro_0402) knock-in strain [34].

\section{Future Perspectives}

In the twelve years since the release of the first Caldicellulosiruptor genome, immense strides towards Caldicellulosiruptor strain development for consolidated bioprocessing have been made. While Caldicellulosiruptor enzymes are robust and have demonstrated promise when heterologously expressed in other systems [104,105,107,109,139-142], engineering C. bescii to produce value added chemicals from plant biomass is now more promising than ever. Critical developments, like the design of $C$. bescii genetic tools, now allow for reverse genetics and heterologous production of synergistic enzymes. Coupled with the previously established genomics, transcriptomics, and proteomics data available for the genus, the stage is set for further advancements towards targeted strain development. Initial reports of an inducible promoter [143] and identification of a redox-responsive regulon [144] in C. bescii are supporting the nascent field of Caldicellulosiruptor synthetic biology. Moving forward, the use of established '-omics' tools to identify additional regulated promoters, optimal ribosomal binding sites, and other $5^{\prime}$ untranslated sequences will be critical for continued advancements in genetic manipulation of the genus Caldicellulosiruptor (see Figure 2).

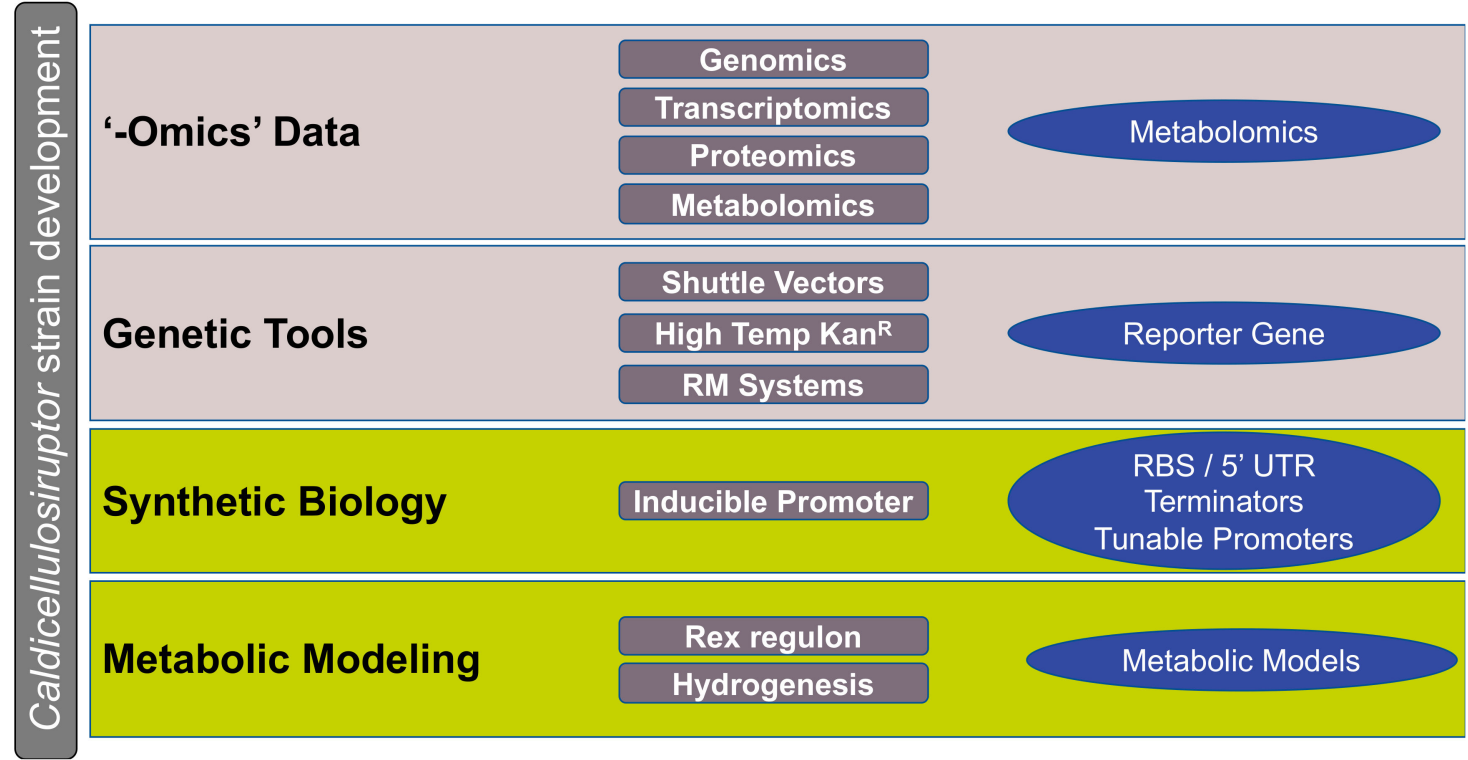

Figure 2. Progress on the generation of data and tools required for Caldicellulosiruptor strain development. Maturing research areas are shaded in light gray, nascent research areas are shaded in light green. Tools and data discussed in this review are listed in dark gray rectangles, tools that require further development for strain development are highlighted in the blue ovals. Image modified from strategies illustrated by Yan and Fong [135].

\section{Conclusions}

Aside from lignocellulose deconstruction, the genus Caldicellulosiruptor is found to be increasingly versatile for other difficult biotransformations. Enzymes identified from the genus have been demonstrated to be useful for food and pharmaceutical production, in addition to textile and paper processing. Additionally, their fermentative physiology is now being investigated for the formation of metal nanoparticles $[145,146]$ and heavy metal reduction [147]. More so now than ever with the benefit of genome sequences and the availability of functional genomics and genetics tools, this non-model environmental genus has the potential to move from the bench to a larger scale as a biotechnological platform microorganism. 
Funding: This research received no external funding.

Conflicts of Interest: The author declares no conflict of interest.

\section{References}

1. Brock, T.D. Life at high temperatures. Science 1967, 158, 1012-1019. [CrossRef]

2. Botha, J.; Mizrachi, E.; Myburg, A.A.; Cowan, D.A. Carbohydrate active enzyme domains from extreme thermophiles: Components of a modular toolbox for lignocellulose degradation. Extremophiles 2018, 22, 1-12. [CrossRef]

3. Blumer-Schuette, S.E.; Brown, S.D.; Sander, K.B.; Bayer, E.A.; Kataeva, I.; Zurawski, J.V.; Conway, J.M.; Adams, M.W.; Kelly, R.M. Thermophilic lignocellulose deconstruction. FEMS Microbiol. Rev. 2014, 38, $393-448$. [CrossRef] [PubMed]

4. McBee, R. The characteristics of Clostridium thermocellum. J. Bacteriol. 1954, 67, 505-506. [CrossRef] [PubMed]

5. Bayer, E.A.; Kenig, R.; Lamed, R. Adherence of Clostridium thermocellum to cellulose. J. Bacteriol. 1983, $156,818-827$. [CrossRef] [PubMed]

6. Lamed, R.; Setter, E.; Kenig, R.; Bayer, E.A. The cellulosome-A discrete cell-surface organelle of Clostridium thermocellum. Biotechnol. Bioeng. 1983, 163-181.

7. Ljungdahl, L.G.; Bryant, F.; Carreira, L.; Saiki, T.; Wiegel, J. Some aspects of thermophilic and extreme thermophilic anaerobic microorganisms. Basic Life Sci. 1981, 18, 397-419.

8. Taya, M.; Hinoki, H.; Kobayashi, T. Tungsten requirement of an extremely thermophilic, cellulolytic anaerobe (strain NA10). Agric. Biol. Chem. 1985, 49, 2513-2515. [CrossRef]

9. Sissons, C.H.; Sharrock, K.R.; Daniel, R.M.; Morgan, H.W. Isolation of cellulolytic anaerobic extreme thermophiles from New Zealand thermal sites. Appl. Environ. Microbiol. 1987, 53, 832-838. [CrossRef]

10. Svetlichnyi, V.A.; Svetlichnaya, T.P.; Chernykh, N.A.; Zavarzin, G.A. Anaerocellum thermophilum Gen. Nov Sp. Nov. an extremely thermophilic cellulolytic eubacterium isolated from hot-springs in the Valley of Geysers. Microbiology 1990, 59, 598-604.

11. Graham, J.E.; Clark, M.E.; Nadler, D.C.; Huffer, S.; Chokhawala, H.A.; Rowland, S.E.; Blanch, H.W.; Clark, D.S.; Robb, F.T. Identification and characterization of a multidomain hyperthermophilic cellulase from an archaeal enrichment. Nat. Commun. 2011, 2, 375. [CrossRef] [PubMed]

12. Liebl, W.; Ruile, P.; Bronnenmeier, K.; Riedel, K.; Lottspeich, F.; Greif, I. Analysis of a Thermotoga maritima DNA fragment encoding two similar thermostable cellulases, CelA and CelB, and characterization of the recombinant enzymes. Microbiology 1996, 142, 2533-2542. [CrossRef] [PubMed]

13. Kang, H.-J.; Uegaki, K.; Fukada, H.; Ishikawa, K. Improvement of the enzymatic activity of the hyperthermophilic cellulase from Pyrococcus horikoshii. Extremophiles 2006, 11, 251-256. [CrossRef] [PubMed]

14. Bergquist, P.L.; Gibbs, M.D.; Morris, D.D.; Te'o, V.S.J.; Saul, D.J.; Morgan, H.W. Molecular diversity of thermophilic cellulolytic and hemicellulolytic bacteria. FEMS Microbiol. Ecol. 1999, 28, 99-110. [CrossRef]

15. Van de Werken, H.J.; Verhaart, M.R.; VanFossen, A.L.; Willquist, K.; Lewis, D.L.; Nichols, J.D.; Goorissen, H.P.; Mongodin, E.F.; Nelson, K.E.; van Niel, E.W.; et al. Hydrogenomics of the extremely thermophilic bacterium Caldicellulosiruptor saccharolyticus. Appl. Environ. Microbiol. 2008, 74, 6720-6729. [CrossRef]

16. Mukherjee, S.; Stamatis, D.; Bertsch, J.; Ovchinnikova, G.; Verezemska, O.; Isbandi, M.; Thomas, A.D.; Ali, R.; Sharma, K.; Kyrpides, N.C.; et al. Genomes OnLine Database (GOLD) v.6: Data updates and feature enhancements. Nucleic Acids Res. 2017, 45, D446-D456. [CrossRef]

17. Dam, P.; Kataeva, I.; Yang, S.-J.; Zhou, F.; Yin, Y.; Chou, W.; Poole, F.L.; Westpheling, J.; Hettich, R.; Giannone, R.; et al. Insights into plant biomass conversion from the genome of the anaerobic thermophilic bacterium Caldicellulosiruptor bescii DSM 6725. Nucleic Acids Res. 2011, 39, 3240-3254. [CrossRef]

18. Bolshakova, E.V.; Ponomariev, A.A.; Novikov, A.A.; Svetlichnyi, V.A.; Velikodvorskaya, G.A. Cloning and expression of genes coding for carbohydrate degrading enzymes of Anaerocellum thermophilum in Escherichia coli. Biochem. Biophys. Res. Commun. 1994, 202, 1076-1080. [CrossRef]

19. Zverlov, V.; Mahr, S.; Riedel, K.; Bronnenmeier, K. Properties and gene structure of a bifunctional cellulolytic enzyme (CelA) from the extreme thermophile 'Anaerocellum thermophilum' with separate glycosyl hydrolase family 9 and 48 catalytic domains. Microbiology 1998, 144, 457-465. [CrossRef] 
20. Te'O, V.S.J.; Saul, D.J.; Bergquist, P.L. celA, another gene coding for a multidomain cellulase from the extreme thermophile Caldocellum saccharolyticum. Appl. Microbiol. Biotechnol. 1995, 43, 291-296.

21. Blumer-Schuette, S.E.; Giannone, R.J.; Zurawski, J.V.; Ozdemir, I.; Ma, Q.; Yin, Y.; Xu, Y.; Kataeva, I.; Poole, F.L., 2nd; Adams, M.W.; et al. Caldicellulosiruptor core and pangenomes reveal determinants for noncellulosomal thermophilic deconstruction of plant biomass. J. Bacteriol. 2012, 194, 4015-4028. [CrossRef] [PubMed]

22. Khan, A.; Mendoza, C.; Hauk, V.J.; Blumer-Schuette, S.E. Genomic and physiological analyses reveal that extremely thermophilic Caldicellulosiruptor changbaiensis deploys uncommon cellulose attachment mechanisms. J. Ind. Microbiol. Biotechnol. 2019, 46, 1251-1263. [CrossRef] [PubMed]

23. Lee, L.L.; Blumer-Schuette, S.E.; Izquierdo, J.A.; Zurawski, J.V.; Loder, A.J.; Conway, J.M.; Elkins, J.G.; Podar, M.; Clum, A.; Jones, P.C.; et al. Genus-wide assessment of lignocellulose utilization in the extremely thermophilic genus Caldicellulosiruptor by genomic, pangenomic, and metagenomic analyses. Appl. Environ. Microbiol. 2018, 84, e02694-17. [CrossRef] [PubMed]

24. Elkins, J.G.; Lochner, A.; Hamilton-Brehm, S.D.; Davenport, K.W.; Podar, M.; Brown, S.D.; Land, M.L.; Hauser, L.J.; Klingeman, D.M.; Raman, B.; et al. Complete genome sequence of the cellulolytic thermophile Caldicellulosiruptor obsidiansis OB47T. J. Bacteriol. 2010, 192, 6099-6100. [CrossRef]

25. Blumer-Schuette, S.E.; Lewis, D.L.; Kelly, R.M. Phylogenetic, microbiological, and glycoside hydrolase diversities within the extremely thermophilic, plant biomass-degrading genus Caldicellulosiruptor. Appl. Environ. Microbiol. 2010, 76, 8084-8092. [CrossRef]

26. Zurawski, J.V.; Conway, J.M.; Lee, L.L.; Simpson, H.J.; Izquierdo, J.A.; Blumer-Schuette, S.; Nookaew, I.; Adams, M.W.; Kelly, R.M. Comparative analysis of extremely thermophilic Caldicellulosiruptor species reveals common and unique cellular strategies for plant biomass utilization. Appl. Environ. Microbiol. 2015, 81, 7159-7170. [CrossRef]

27. Meng, D.-D.; Ying, Y.; Zhang, K.-D.; Lu, M.; Li, F.-L. Depiction of carbohydrate-active enzyme diversity in Caldicellulosiruptor sp. F32 at the genome level reveals insights into distinct polysaccharide degradation features. Mol. Biosyst. 2015, 11, 3164-3173. [CrossRef]

28. VanFossen, A.L.; Verhaart, M.R.A.; Kengen, S.M.W.; Kelly, R.M. Carbohydrate utilization patterns for the extremely thermophilic bacterium Caldicellulosiruptor saccharolyticus reveal broad growth substrate preferences. Appl. Environ. Microbiol. 2009, 75, 7718-7724. [CrossRef]

29. Blumer-Schuette, S.E.; Zurawski, J.V.; Conway, J.M.; Khatibi, P.; Lewis, D.L.; Li, Q.; Chiang, V.L.; Kelly, R.M. Caldicellulosiruptor saccharolyticus transcriptomes reveal consequences of chemical pretreatment and genetic modification of lignocellulose. Microb. Biotechnol. 2017, 10, 1546-1557. [CrossRef]

30. Lochner, A.; Giannone, R.J.; Rodriguez, M.; Shah, M.B.; Mielenz, J.R.; Keller, M.; Antranikian, G.; Graham, D.E.; Hettich, R.L. Use of label-free quantitative proteomics to distinguish the secreted cellulolytic systems of Caldicellulosiruptor bescii and Caldicellulosiruptor obsidiansis. Appl. Environ. Microbiol. 2011, 77, 4042-4054. [CrossRef]

31. Miroshnichenko, M.L.; Kublanov, I.V.; Kostrikina, N.A.; Tourova, T.P.; Kolganova, T.V.; Birkeland, N.-K.; Bonch-Osmolovskaya, E.A. Caldicellulosiruptor kronotskyensis sp. nov. and Caldicellulosiruptor hydrothermalis sp. nov., two extremely thermophilic, cellulolytic, anaerobic bacteria from Kamchatka thermal springs. Int. J. Syst. Evol. Microbiol. 2008, 58, 1492-1496. [CrossRef] [PubMed]

32. Rainey, F.A.; Janssen, P.H.; Morgan, H.W.; Stackebrandt, E. A biphasic approach to the determination of the phenotypic and genotypic diversity of some anaerobic, cellulolytic, thermophilic, rod-shaped bacteria. Antonie Leeuwenhoek 1993, 64, 341-355. [CrossRef] [PubMed]

33. Fujino, T.; Beguin, P.; Aubert, J.P. Organization of a Clostridium thermocellum gene-cluster encoding the cellulosomal scaffolding protein CipA and a protein possibly involved in attachment of the cellulosome to the cell-surface. J. Bacteriol. 1993, 175, 1891-1899. [CrossRef] [PubMed]

34. Conway, J.M.; Pierce, W.S.; Le, J.H.; Harper, G.W.; Wright, J.H.; Tucker, A.L.; Zurawski, J.V.; Lee, L.L.; Blumer-Schuette, S.E.; Kelly, R.M. Multidomain, surface layer-associated glycoside hydrolases contribute to plant polysaccharide degradation by Caldicellulosiruptor species. J. Biol. Chem. 2016, 291, 6732-6747. [CrossRef]

35. Ozdemir, I.; Blumer-Schuette, S.E.; Kelly, R.M. S-layer homology domain proteins Csac_0678 and Csac_2722 are implicated in plant polysaccharide deconstruction by the extremely thermophilic bacterium Caldicellulosiruptor saccharolyticus. Appl. Environ. Microbiol. 2012, 78, 768-777. [CrossRef] 
36. Blumer-Schuette, S.E.; Alahuhta, M.; Conway, J.M.; Lee, L.L.; Zurawski, J.V.; Giannone, R.J.; Hettich, R.L.; Lunin, V.V.; Himmel, M.E.; Kelly, R.M. Discrete and structurally unique proteins (tāpirins) mediate attachment of extremely thermophilic Caldicellulosiruptor species to cellulose. J. Biol. Chem. 2015, 290, 10645-10656. [CrossRef]

37. Lee, L.L.; Hart, W.S.; Lunin, V.V.; Alahuhta, M.; Bomble, Y.J.; Himmel, M.E.; Blumer-Schuette, S.E.; Adams, M.W.W.; Kelly, R.M. Comparative biochemical and structural analysis of novel cellulose binding proteins (tāpirins) from extremely thermophilic Caldicellulosiruptor species. Appl. Environ. Microbiol. 2018, 85, e01983-18. [CrossRef]

38. Reynolds, P.H.S.; Sissons, C.H.; Daniel, R.M.; Morgan, H.W. Comparison of cellulolytic activities in Clostridium thermocellum and three thermophilic, cellulolytic anaerobes. Appl. Environ. Microbiol. 1986, 51, 12-17. [CrossRef]

39. Bredholt, S.; Mathrani, I.M.; Ahring, B.K. Extremely thermophilic cellulolytic anaerobes from icelandic hot springs. Antonie Leeuwenhoek 1995, 68, 263-271. [CrossRef]

40. Love, D.R.; Fisher, R.; Bergquist, P.L. Sequence structure and expression of a cloned $\beta$-glucosidase gene from an extreme thermophile. Mol. Gen. Genet. 1988, 213, 84-92. [CrossRef]

41. Lüthi, E.; Jasmat, N.B.; Grayling, R.A.; Love, D.R.; Bergquist, P.L. Cloning, sequence analysis, and expression in Escherichia coli of a gene coding for a beta-mannanase from the extremely thermophilic bacterium "Caldocellum saccharolyticum". Appl. Environ. Microbiol. 1991, 57, 694-700. [CrossRef] [PubMed]

42. Gibbs, M.D.; Saul, D.J.; Lüthi, E.; Bergquist, P.L. The beta-mannanase from" Caldocellum saccharolyticum" is part of a multidomain enzyme. Appl. Environ. Microbiol. 1992, 58, 3864-3867. [CrossRef] [PubMed]

43. Baker, G.C.; Smith, J.J.; Cowan, D.A. Review and re-analysis of domain-specific 16S primers. J. Microbiol. Methods 2003, 55, 541-555. [CrossRef] [PubMed]

44. Kádár, Z.; De Vrije, T.; Budde, M.; Szengyel, Z.; Réczey, K.; Claassen, P. Hydrogen production from paper sludge hydrolysate. Appl. Biochem. Biotechnol. 2003, 107, 557-566. [CrossRef]

45. Ivanova, G.; Rákhely, G.; Kovács, K.L. Hydrogen production from biopolymers by Caldicellulosiruptor saccharolyticus and stabilization of the system by immobilization. Int. J. Hydrog. Energy 2008, 33, 6953-6961. [CrossRef]

46. De Vrije, T.; Bakker, R.; Budde, M.; Lai, M.; Mars, A.; Claassen, P. Efficient hydrogen production from the lignocellulosic energy crop Miscanthus by the extreme thermophilic bacteria Caldicellulosiruptor saccharolyticus and Thermotoga neapolitana. Biotechnol. Biofuels 2009, 2, 12. [CrossRef]

47. Talluri, S.; Raj, S.M.; Christopher, L.P. Consolidated bioprocessing of untreated switchgrass to hydrogen by the extreme thermophile Caldicellulosiruptor saccharolyticus DSM 8903. Bioresour. Technol. 2013, 139, 272-279. [CrossRef]

48. Sahm, K.; John, P.; Nacke, H.; Wemheuer, B.; Grote, R.; Daniel, R.; Antranikian, G. High abundance of heterotrophic prokaryotes in hydrothermal springs of the Azores as revealed by a network of 16S rRNA gene-based methods. Extremophiles 2013, 17, 649-662. [CrossRef]

49. Orlygsson, J.; Sigurbjornsdottir, M.A.; Bakken, H.E. Bioprospecting thermophilic ethanol and hydrogen producing bacteria from hot springs in Iceland. Icel. Agric. Sci. 2010, 23, 73-85.

50. Kublanov, I.V.; Perevalova, A.A.; Slobodkina, G.B.; Lebedinsky, A.V.; Bidzhieva, S.K.; Kolganova, T.V.; Kaliberda, E.N.; Rumsh, L.D.; Haertle, T.; Bonch-Osmolovskaya, E.A. Biodiversity of thermophilic prokaryotes with hydrolytic activities in hot springs of Uzon Caldera, Kamchatka (Russia). Appl. Environ. Microbiol. 2009, 75, 286-291. [CrossRef]

51. Sayeh, R.; Birrien, J.L.; Alain, K.; Barbier, G.; Hamdi, M.; Prieur, D. Microbial diversity in Tunisian geothermal springs as detected by molecular and culture-based approaches. Extremophiles 2010, 14, 501-514. [CrossRef] [PubMed]

52. Vishnivetskaya, T.A.; Hamilton-Brehm, S.D.; Podar, M.; Mosher, J.J.; Palumbo, A.V.; Phelps, T.J.; Keller, M.; Elkins, J.G. Community analysis of plant biomass-degrading microorganisms from Obsidian Pool, Yellowstone National Park. Microb. Ecol. 2015, 69, 333-345. [CrossRef] [PubMed]

53. Hniman, A.; Prasertsan, P.; O-Thong, S. Community analysis of thermophilic hydrogen-producing consortia enriched from Thailand hot spring with mixed xylose and glucose. Int. J. Hydrog Energy 2011, 36, 14217-14226. [CrossRef]

54. Liu, Z.; Zhao, C.; Deng, Y.; Huang, Y.; Liu, B. Characterization of a thermostable recombinant $\beta$-galactosidase from a thermophilic anaerobic bacterial consortium YTY-70. Biotechnol. Biotechnol. Equip. 2015, 29, 547-554. [CrossRef] 
55. Huang, C.Y.; Patel, B.K.; Mah, R.A.; Baresi, L. Caldicellulosiruptor owensensis sp. nov., an anaerobic, extremely thermophilic, xylanolytic bacterium. Int. J. Syst. Bacteriol. 1998, 48 Pt 1, 91-97. [CrossRef]

56. Ying, Y.; Meng, D.; Chen, X.; Li, F. An extremely thermophilic anaerobic bacterium Caldicellulosiruptor sp. F32 exhibits distinctive properties in growth and xylanases during xylan hydrolysis. Enzym. Microb. Technol. 2013. [CrossRef]

57. Qiu, C.S.; Wen, J.P.; Jia, X.Q. Extreme-thermophilic biohydrogen production from lignocellulosic bioethanol distillery wastewater with community analysis of hydrogen-producing microflora. Int. J. Hydrog. Energy 2011, 36, 8243-8251. [CrossRef]

58. Pandit, R.J.; Hinsu, A.T.; Patel, S.H.; Jakhesara, S.J.; Koringa, P.G.; Bruno, F.; Psifidi, A.; Shah, S.V.; Joshi, C.G. Microbiota composition, gene pool and its expression in Gir cattle (Bos indicus) rumen under different forage diets using metagenomic and metatranscriptomic approaches. Syst. Appl. Microbiol. 2018, 41, 374-385. [CrossRef]

59. Pandit, R.J.; Hinsu, A.T.; Patel, N.V.; Koringa, P.G.; Jakhesara, S.J.; Thakkar, J.R.; Shah, T.M.; Limon, G.; Psifidi, A.; Guitian, J.; et al. Microbial diversity and community composition of caecal microbiota in commercial and indigenous Indian chickens determined using $16 \mathrm{~S}$ rDNA amplicon sequencing. Microbiome 2018, 6. [CrossRef]

60. Pollo, S.M.J.; Zhaxybayeva, O.; Nesbø, C.L. Insights into thermoadaptation and the evolution of mesophily from the bacterial phylum Thermotogae. Can. J. Microbiol. 2015, 61, 655-670. [CrossRef]

61. Cheng, H.J.; Asakura, Y.; Kanda, K.; Fukui, R.; Kawano, Y.; Okugawa, Y.; Tashiro, Y.; Sakai, K. Dynamic bacterial community changes in the autothermal thermophilic aerobic digestion process with cell lysis activities, shaking and temperature increase. J. Biosci. Bioeng. 2018, 126, 196-204. [CrossRef] [PubMed]

62. Lu, F.; Bize, A.; Guillot, A.; Monnet, V.; Madigou, C.; Chapleur, O.; Mazeas, L.; He, P.J.; Bouchez, T. Metaproteomics of cellulose methanisation under thermophilic conditions reveals a surprisingly high proteolytic activity. ISME J. 2014, 8, 88-102. [CrossRef] [PubMed]

63. Pandit, P.D.; Gulhane, M.K.; Khardenavis, A.A.; Purohit, H.J. Mining of hemicellulose and lignin degrading genes from differentially enriched methane producing microbial community. Bioresour. Technol. 2016, 216, 923-930. [CrossRef] [PubMed]

64. Zhang, F.; Yang, J.-H.; Dai, K.; Ding, Z.-W.; Wang, L.-G.; Li, Q.-R.; Gao, F.-M.; Zeng, R.J. Microbial dynamics of the extreme-thermophilic $\left(70^{\circ} \mathrm{C}\right)$ mixed culture for hydrogen production in a chemostat. Int. J. Hydrog. Energy 2016, 41, 11072-11080. [CrossRef]

65. Wirth, R.; Kovács, E.; Maróti, G.; Bagi, Z.; Rákhely, G.; Kovács, K.L. Characterization of a biogas-producing microbial community by short-read next generation DNA sequencing. Biotechnol. Biofuels 2012, 5, 41. [CrossRef]

66. Svetlitchnyi, V.A.; Kensch, O.; Falkenhan, D.A.; Korseska, S.G.; Lippert, N.; Prinz, M.; Sassi, J.; Schickor, A.; Curvers, S. Single-step ethanol production from lignocellulose using novel extremely thermophilic bacteria. Biotechnol. Biofuels 2013, 6, 31. [CrossRef]

67. Van Groenestijn, J.W.; Geelhoed, J.S.; Goorissen, H.P.; Meesters, K.P.M.; Stams, A.J.M.; Claassen, P.A.M. Performance and population analysis of a non-sterile trickle bed reactor inoculated with Caldicellulosiruptor saccharolyticus, a thermophilic hydrogen producer. Biotechnol. Bioeng. 2009, 102, 1361-1367. [CrossRef] [PubMed]

68. Mediavilla, O.; Geml, J.; Olaizola, J.; Oria-de-Rueda, J.A.; Baldrian, P.; Martín-Pinto, P. Effect of forest fire prevention treatments on bacterial communities associated with productive Boletus edulis sites. Microb. Biotechnol. 2019, 12, 1188-1198. [CrossRef]

69. Zhang, G.X.; Dong, H.L.; Jiang, H.C.; Xu, Z.Q.; Eberl, D.D. Unique microbial community in drilling fluids from Chinese continental scientific drilling. Geomicrobiol. J. 2006, 23, 499-514. [CrossRef]

70. Nishihara, A.; Haruta, S.; McGlynn, S.E.; Thiel, V.; Matsuura, K. Nitrogen fixation in thermophilic chemosynthetic microbial communities depending on hydrogen, sulfate, and carbon dioxide. Microb. Environ. 2018, 33, 10-18. [CrossRef]

71. Narihiro, T.; Terada, T.; Kikuchi, K.; Iguchi, A.; Ikeda, M.; Yamauchi, T.; Shiraishi, K.; Kamagata, Y.; Nakamura, K.; Sekiguchi, Y. Comparative analysis of bacterial and archaeal communities in methanogenic sludge granules from upflow anaerobic sludge blanket reactors treating various food-processing, high-strength organic wastewaters. Microb. Environ. 2009, 24, 88-96. [CrossRef] [PubMed]

72. Lochner, A.; Giannone, R.J.; Keller, M.; Antranikian, G.; Graham, D.E.; Hettich, R.L. Label-free quantitative proteomics for the extremely thermophilic bacterium Caldicellulosiruptor obsidiansis reveal distinct 
abundance patterns upon growth on cellobiose, crystalline cellulose, and switchgrass. J. Proteome Res. 2011, 10, 5302-5314. [CrossRef] [PubMed]

73. Hudson, J.A.; Morgan, H.W.; Daniel, R.M. A survey of cellulolytic anaerobic thermophiles from hot springs. Syst. Appl. Microbiol. 1990, 13, 72-76. [CrossRef]

74. Conway, J.M.; McKinley, B.S.; Seals, N.L.; Hernandez, D.; Khatibi, P.A.; Poudel, S.; Giannone, R.J.; Hettich, R.L.; Williams-Rhaesa, A.M.; Lipscomb, G.L.; et al. Functional analysis of the glucan degradation locus in Caldicellulosiruptor bescii reveals essential roles of component glycoside hydrolases in plant biomass deconstruction. Appl. Environ. Microbiol. 2017, 83, e01828-17. [CrossRef]

75. Sota, H.; Honda, H.; Taya, M.; Iijima, S.; Kobayashi, T. Diversity of cellulases produced by a thermophilic anaerobe strain NA10. J. Ferment. Bioeng. 1989, 68, 183-187. [CrossRef]

76. Saul, D.J.; Williams, L.C.; Grayling, R.A.; Chamley, L.W.; Love, D.R.; Bergquist, P.L. celB, a gene coding for a bifunctional cellulase from the extreme thermophile "Caldocellum saccharolyticum". Appl. Environ. Microbiol. 1990, 56, 3117-3124. [CrossRef]

77. Gibbs, M.D.; Reeves, R.A.; Farrington, G.K.; Anderson, P.; Williams, D.P.; Bergquist, P.L. Multidomain and multifunctional glycosyl hydrolases from the extreme thermophile Caldicellulosiruptor Isolate Tok7B.1. Curr. Microbiol. 2000, 40, 333-340. [CrossRef]

78. Morris, D.D.; Reeves, R.A.; Gibbs, M.D.; Saul, D.J.; Bergquist, P.L. Correction of the beta-mannanase domain of the celC pseudogene from Caldocellulosiruptor saccharolyticus and activity of the gene product on kraft pulp. Appl. Environ. Microbiol. 1995, 61, 2262-2269. [CrossRef] [PubMed]

79. Conway, J.M.; Crosby, J.R.; McKinley, B.S.; Seals, N.L.; Adams, M.W.W.; Kelly, R.M. Parsing in vivo and in vitro contributions to microcrystalline cellulose hydrolysis by multidomain glycoside hydrolases in the Caldicellulosiruptor bescii secretome. Biotechnol. Bioeng. 2018, 115. [CrossRef] [PubMed]

80. Yi, Z.; Su, X.; Revindran, V.; Mackie, R.I.; Cann, I. Molecular and Biochemical analyses of CbCel9A/Cel48A, a highly secreted multi-modular cellulase by Caldicellulosiruptor bescii during growth on crystalline cellulose. PLoS ONE 2013, 8, e84172. [CrossRef] [PubMed]

81. Brunecky, R.; Alahuhta, M.; Xu, Q.; Donohoe, B.S.; Crowley, M.F.; Kataeva, I.A.; Yang, S.-J.; Resch, M.G.; Adams, M.W.W.; Lunin, V.V.; et al. Revealing nature's cellulase diversity: The digestion mechanism of Caldicellulosiruptor bescii CelA. Science 2013, 342, 1513-1516. [CrossRef] [PubMed]

82. Brunecky, R.; Donohoe, B.S.; Yarbrough, J.M.; Mittal, A.; Scott, B.R.; Ding, H.; Ii, L.E.T.; Russell, J.F.; Chung, D.; Westpheling, J.; et al. The multi domain Caldicellulosiruptor bescii CelA cellulase excels at the hydrolysis of crystalline cellulose. Sci. Rep. 2017, 7, 9622. [CrossRef] [PubMed]

83. Kataeva, I.; Foston, M.B.; Yang, S.-J.; Pattathil, S.; Biswal, A.K.; Poole, F.L.; Basen, M.; Rhaesa, A.M.; Thomas, T.P.; Azadi, P.; et al. Carbohydrate and lignin are simultaneously solubilized from unpretreated switchgrass by microbial action at high temperature. Energy Environ. Sci. 2013, 6, 2186-2195. [CrossRef]

84. Tolbert, A.K.; Young, J.M.; Jung, S.; Chung, D.; Passian, A.; Westpheling, J.; Ragauskus, A.J. Surface Characterization of Populus during Caldicellulosiruptor bescii Growth by TOF-SIMS Analysis. ACS Sustain. Chem. Eng. 2017, 5, 2084-2089. [CrossRef]

85. Young, J.; Chung, D.; Bomble, Y.J.; Himmel, M.E.; Westpheling, J. Deletion of Caldicellulosiruptor bescii CelA reveals its crucial role in the deconstruction of lignocellulosic biomass. Biotechnol. Biofuels 2014, 7, 142. [CrossRef] [PubMed]

86. Williams-Rhaesa, A.M.; Poole, F.L.; Dinsmore, J.T.; Lipscomb, G.L.; Rubinstein, G.M.; Scott, I.M.; Conway, J.M.; Lee, L.L.; Khatibi, P.A.; Kelly, R.M.; et al. Genome stability in engineered strains of the extremely thermophilic, lignocellulose-degrading bacterium Caldicellulosiruptor bescii. Appl. Environ. Microbiol. 2017, 83, e00444-17. [CrossRef]

87. Kim, S.-K.; Chung, D.; Himmel, M.E.; Bomble, Y.J.; Westpheling, J. Engineering the N-terminal end of CelA results in improved performance and growth of Caldicellulosiruptor bescii on crystalline cellulose. Biotechnol. Bioeng. 2017, 114, 945-950. [CrossRef]

88. Brunecky, R.; Chung, D.; Sarai, N.S.; Hengge, N.; Russell, J.F.; Young, J.; Mittal, A.; Pason, P.; Wall, T.V.; Michener, W.; et al. High activity CAZyme cassette for improving biomass degradation in thermophiles. Biotechnol. Biofuels 2018, 11, 22. [CrossRef]

89. Chung, D.; Young, J.; Bomble, Y.J.; Vander Wall, T.A.; Groom, J.; Himmel, M.E.; Westpheling, J. Homologous expression of the Caldicellulosiruptor bescii CelA reveals that the extracellular protein is glycosylated. PLoS ONE 2015, 10, 11. [CrossRef] 
90. Chung, D.; Sarai, N.S.; Knott, B.C.; Hengge, N.; Russell, J.F.; Yarbrough, J.M.; Brunecky, R.; Young, J.; Supekar, N.; Wall, T.V.; et al. Glycosylation is vital for industrial performance of hyperactive cellulases. ACS Sustain. Chem. Eng. 2019, 7, 4792-4800. [CrossRef]

91. Russell, J.; Kim, S.-K.; Duma, J.; Nothaft, H.; Himmel, M.E.; Bomble, Y.J.; Szymanski, C.M.; Westpheling, J. Deletion of a single glycosyltransferase in Caldicellulosiruptor bescii eliminates protein glycosylation and growth on crystalline cellulose. Biotechnol. Biofuels 2018, 11, 259. [CrossRef] [PubMed]

92. Ye, L.; Su, X.; Schmitz, G.E.; Moon, Y.H.; Zhang, J.; Mackie, R.I.; Cann, I.K.O. Molecular and biochemical analyses of the GH44 Module of CbMan5B/Cel44A, a bifunctional enzyme from the hyperthermophilic bacterium Caldicellulosiruptor bescii. Appl. Environ. Microbiol. 2012, 78, 7048-7059. [CrossRef] [PubMed]

93. Lu, Y.; Zhang, Y.H.P.; Lynd, L.R. Enzyme-microbe synergy during cellulose hydrolysis by Clostridium thermocellum. Proc. Natl. Acad. Sci. USA 2006, 103, 16165-16169. [CrossRef] [PubMed]

94. Conway, J.M.; Crosby, J.R.; Hren, A.P.; Southerland, R.T.; Lee, L.L.; Lunin, V.V.; Alahuhta, P.; Himmel, M.E.; Bomble, Y.J.; Adams, M.W.W.; et al. Novel multidomain, multifunctional glycoside hydrolases from highly lignocellulolytic Caldicellulosiruptor species. AIChE J. 2018, 64, 4218-4228. [CrossRef]

95. Su, X.; Han, Y.; Dodd, D.; Moon, Y.H.; Yoshida, S.; Mackie, R.I.; Cann, I.K.O. Reconstitution of a thermostable xylan-degrading enzyme mixture from the bacterium Caldicellulosiruptor bescii. Appl. Environ. Microbiol. 2013, 79, 1481-1490. [CrossRef] [PubMed]

96. Peng, X.; Qiao, W.; Mi, S.; Jia, X.; Su, H.; Han, Y. Characterization of hemicellulase and cellulase from the extremely thermophilic bacterium Caldicellulosiruptor owensensis and their potential application for bioconversion of lignocellulosic biomass without pretreatment. Biotechnol. Biofuels 2015, 8, 131. [CrossRef]

97. Jia, X.J.; Han, Y.J. The extracellular endo-1,4-xylanase with multidomain from the extreme thermophile Caldicellulosiruptor lactoaceticus is specific for insoluble xylan degradation. Biotechnol. Biofuels 2019, 12. [CrossRef]

98. Kim, S.-K.; Chung, D.; Himmel, M.E.; Bomble, Y.J.; Westpheling, J. Heterologous expression of family 10 xylanases from Acidothermus cellulolyticus enhances the exoproteome of Caldicellulosiruptor bescii and growth on xylan substrates. Biotechnol. Biofuels 2016, 9, 176. [CrossRef]

99. Artzi, L.; Bayer, E.A.; Morais, S. Cellulosomes: Bacterial nanomachines for dismantling plant polysaccharides. Nat. Rev. Microbiol. 2017, 15, 83-95. [CrossRef]

100. Leis, B.; Held, C.; Bergkemper, F.; Dennemarck, K.; Steinbauer, R.; Reiter, A.; Mechelke, M.; Moerch, M.; Graubner, S.; Liebl, W.; et al. Comparative characterization of all cellulosomal cellulases from Clostridium thermocellum reveals high diversity in endoglucanase product formation essential for complex activity. Biotechnol. Biofuels 2017, 10, 240. [CrossRef]

101. Gefen, G.; Anbar, M.; Morag, E.; Lamed, R.; Bayer, E.A. Enhanced cellulose degradation by targeted integration of a cohesin-fused $\beta$-glucosidase into the Clostridium thermocellum cellulosome. Proc. Natl. Acad. Sci. USA 2012, 109, 10298-10303. [CrossRef] [PubMed]

102. Prawitwong, P.; Waeonukul, R.; Tachaapaikoon, C.; Pason, P.; Ratanakhanokchai, K.; Deng, L.; Sermsathanaswadi, J.; Septiningrum, K.; Mori, Y.; Kosugi, A. Direct glucose production from lignocellulose using Clostridium thermocellum cultures supplemented with a thermostable $\beta$-glucosidase. Biotechnol. Biofuels 2013, 6, 184. [CrossRef] [PubMed]

103. Zhang, J.; Liu, S.; Li, R.; Hong, W.; Xiao, Y.; Feng, Y.; Cui, Q.; Liu, Y.-J. Efficient whole-cell-catalyzing cellulose saccharification using engineered Clostridium thermocellum. Biotechnol. Biofuels 2017, 10, 124. [CrossRef] [PubMed]

104. Li, X.; Xiao, Y.; Feng, Y.; Li, B.; Li, W.; Cui, Q. The spatial proximity effect of beta-glucosidase and cellulosomes on cellulose degradation. Enzym. Microb. Technol. 2018, 115, 52-61. [CrossRef]

105. Galanopoulou, A.P.; Moraïs, S.; Georgoulis, A.; Morag, E.; Bayer, E.A.; Hatzinikolaou, D.G. Insights into the functionality and stability of designer cellulosomes at elevated temperatures. Appl. Microbiol. Biotechnol. 2016, 100, 8731-8743. [CrossRef]

106. Kahn, A.; Morais, S.; Galanopoulou, A.P.; Chung, D.; Sarai, N.S.; Hengge, N.; Hatzinikolaou, D.G.; Himmel, M.E.; Bomble, Y.J.; Bayer, E.A. Creation of a functional hyperthermostable designer cellulosome. Biotechnol. Biofuels 2019, 12. [CrossRef]

107. Xu, H.; Han, D.; Xu, Z. Expression of heterologous cellulases in Thermotoga sp. strain RQ2. Biomed. Res. Int. 2015, 2105, 304523. [CrossRef] 
108. Park, J.I.; Steen, E.J.; Burd, H.; Evans, S.S.; Redding-Johnson, A.M.; Batth, T.; Benke, P.I.; D’haeseleer, P.; Sun, N.; Sale, K.L.; et al. A thermophilic ionic liquid-tolerant cellulase cocktail for the production of cellulosic biofuels. PLoS ONE 2012, 7, e37010. [CrossRef]

109. Campen, S.A.; Lynn, J.; Sibert, S.J.; Srikrishnan, S.; Phatale, P.; Feldman, T.; Guenther, J.M.; Hiras, J.; Tran, Y.T.A.; Singer, S.W.; et al. Expression of naturally ionic liquid-tolerant thermophilic cellulases in Aspergillus niger. PLoS ONE 2017, 12, e0189604. [CrossRef]

110. Honda, H.; Naito, H.; Taya, M.; Iijima, S.; Kobayashi, T. Cloning and expression in Escherichia coli of a Thermoanaerobacter cellulolyticus gene coding for heat-stable $\beta$-glucanase. Appl. Microbiol. Biotechnol. 1987, 25, 480-483. [CrossRef]

111. Honda, H.; Saito, T.; Iijima, S.; Kobayashi, T. Isolation of a new cellulase gene from a thermophilic anaerobe and its expression in Escherichia coli. Appl. Microbiol. Biotechnol. 1988, 29, 264-268. [CrossRef]

112. Honda, H.; Iijima, S.; Kobayashi, T. Cloning and expression in Sacharomyces cerevisiae of an endo- $\$$-glucanase gene from a thermophilic cellulolytic anaerobe. Appl. Microbiol. Biotechnol. 1988, 28, 57-58. [CrossRef]

113. Saito, T.; Suzuki, T.; Hayashi, A.; Honda, H.; Taya, M.; Iijima, S.; Kobayashi, T. Expression of a thermostable cellulase gene from a thermophilic anaerobe in Saccharomyces cerevisiae. J. Ferm. Bioeng. 1990, 69, 282-286. [CrossRef]

114. Olson, D.G.; McBride, J.E.; Joe Shaw, A.; Lynd, L.R. Recent progress in consolidated bioprocessing. Curr. Opin. Biotechnol. 2012, 23, 396-405. [CrossRef]

115. Yan, Q.; Fong, S.S. Challenges and advances for genetic engineering of non-model bacteria and uses in consolidated bioprocessing. Front. Microbiol. 2017, 8. [CrossRef] [PubMed]

116. Chung, D.-H.; Huddleston, J.; Farkas, J.; Westpheling, J. Identification and characterization of CbeI, a novel thermostable restriction enzyme from Caldicellulosiruptor bescii DSM 6725 and a member of a new subfamily of HaeIII-like enzymes. J. Ind. Microbiol. Biotechnol. 2011, 38, 1867-1877. [CrossRef]

117. Chung, D.; Farkas, J.; Westpheling, J. Overcoming restriction as a barrier to DNA transformation in Caldicellulosiruptor species results in efficient marker replacement. Biotechnol. Biofuels 2013, 6, 82. [CrossRef]

118. Farkas, J.; Chung, D.; Cha, M.; Copeland, J.; Grayeski, P.; Westpheling, J. Improved growth media and culture techniques for genetic analysis and assessment of biomass utilization by Caldicellulosiruptor bescii. J. Ind. Microbiol. Biotechnol. 2013, 40,41-49. [CrossRef]

119. Cha, M.; Chung, D.; Elkins, J.G.; Guss, A.M.; Westpheling, J. Metabolic engineering of Caldicellulosiruptor bescii yields increased hydrogen production from lignocellulosic biomass. Biotechnol. Biofuels 2013, 6, 85. [CrossRef]

120. Lipscomb, G.L.; Conway, J.M.; Blumer-Schuette, S.E.; Kelly, R.M.; Adams, M.W.W. A highly thermostable kanamycin resistance marker expands the tool kit for genetic manipulation of Caldicellulosiruptor bescii. Appl. Environ. Microbiol. 2016, 82, 4421-4428. [CrossRef]

121. Chung, D.; Cha, M.; Guss, A.M.; Westpheling, J. Direct conversion of plant biomass to ethanol by engineered Caldicellulosiruptor bescii. Proc. Natl. Acad. Sci. USA 2014, 111, 8931-8936. [CrossRef] [PubMed]

122. Chung, D.; Cha, M.; Farkas, J.; Westpheling, J. Construction of a stable replicating shuttle vector for Caldicellulosiruptor species: Use for extending genetic methodologies to other members of this genus. PLoS ONE 2013, 8, e62881. [CrossRef] [PubMed]

123. Clausen, A.; Mikkelsen, M.J.; Schroder, I.; Ahring, B.K. Cloning, sequencing, and sequence analysis of two novel plasmids from the thermophilic anaerobic bacterium Anaerocellum thermophilum. Plasmid 2004, 52, 131-138. [CrossRef]

124. Groom, J.; Chung, D.; Olson, D.G.; Lynd, L.R.; Guss, A.M.; Westpheling, J. Promiscuous plasmid replication in thermophiles: Use of a novel hyperthermophilic replicon for genetic manipulation of Clostridium thermocellum at its optimum growth temperature. Metab. Eng. Commun. 2016, 3, 30-38. [CrossRef]

125. Bielen, A.A.M.; Verhaart, M.R.A.; van der Oost, J.; Kengen, S.W.M. Biohydrogen production by the thermophilic bacterium Caldicellulosiruptor saccharolyticus: Current status and perspectives. Life 2013, 3, 52-85. [CrossRef] [PubMed]

126. Björkmalm, J.; Byrne, E.; van Niel, E.W.J.; Willquist, K. A non-linear model of hydrogen production by Caldicellulosiruptor saccharolyticus for diauxic-like consumption of lignocellulosic sugar mixtures. Biotechnol. Biofuels 2018, 11, 175. [CrossRef] 
127. Soto, L.R.; Byrne, E.; van Niel, E.W.J.; Sayed, M.; Villanueva, C.C.; Hatti-Kaul, R. Hydrogen and polyhydroxybutyrate production from wheat straw hydrolysate using Caldicellulosiruptor species and Ralstonia eutropha in a coupled process. Bioresour. Technol. 2019, 272, 259-266. [CrossRef]

128. Peng, X.W.; Kelly, R.M.; Han, Y.J. Sequential processing with fermentative Caldicellulosiruptor kronotskyensis and chemolithoautotrophic Cupriavidus necator for converting rice straw and $\mathrm{CO} 2$ to polyhydroxybutyrate. Biotechnol. Bioeng. 2018, 115, 1624-1629. [CrossRef]

129. Roh, Y.; Liu, S.V.; Li, G.; Huang, H.; Phelps, T.J.; Zhou, J. Isolation and characterization of metal-reducing Thermoanaerobacter strains from deep subsurface environments of the Piceance Basin, Colorado. Appl. Environ. Microbiol. 2002, 68, 6013-6020. [CrossRef]

130. Williams-Rhaesa, A.M.; Rubinstein, G.M.; Scott, I.M.; Lipscomb, G.L.; Poole, I.; Farris, L.; Kelly, R.M.; Adams, M.W.W. Engineering redox-balanced ethanol production in the cellulolytic and extremely thermophilic bacterium, Caldicellulosiruptor bescii. Metab. Eng. Commun. 2018, 7, e00073. [CrossRef]

131. Yang, S.-J.; Kataeva, I.; Wiegel, J.; Yin, Y.; Dam, P.; Xu, Y.; Westpheling, J.; Adams, M.W.W. Classification of 'Anaerocellum thermophilum' strain DSM 6725 as Caldicellulosiruptor bescii sp. nov. Int. J. Syst. Evol. Microbiol. 2010, 60, 2011-2015. [CrossRef] [PubMed]

132. Onyenwoke, R.U.; Kevbrin, V.V.; Lysenko, A.M.; Wiegel, J. Thermoanaerobacter pseudethanolicus sp. nov., a thermophilic heterotrophic anaerobe from Yellowstone National Park. Int. J. Syst. Evol. Microbiol. 2007, 57, 2191-2193. [CrossRef] [PubMed]

133. Chung, D.; Cha, M.; Snyder, E.N.; Elkins, J.G.; Guss, A.M.; Westpheling, J. Cellulosic ethanol production via consolidated bioprocessing at $75^{\circ} \mathrm{C}$ by engineered Caldicellulosiruptor bescii. Biotechnol. Biofuels 2015, 8, 163. [CrossRef] [PubMed]

134. Chung, D.; Verbeke, T.J.; Cross, K.L.; Westpheling, J.; Elkins, J.G. Expression of a heat-stable NADPH-dependent alcohol dehydrogenase in Caldicellulosiruptor bescii results in furan aldehyde detoxification. Biotechnol. Biofuels 2015, 8, 102. [CrossRef]

135. Kim, S.-K.; Chung, D.; Himmel, M.E.; Bomble, Y.J.; Westpheling, J. Heterologous expression of a $\beta$-d-glucosidase in Caldicellulosiruptor bescii has a surprisingly modest effect on the activity of the exoproteome and growth on crystalline cellulose. J. Ind. Microbiol. Biotechnol. 2017, 44, 1643-1651. [CrossRef]

136. Kim, S.-K.; Himmel, M.E.; Bomble, Y.J.; Westpheling, J. Expression of a cellobiose phosphorylase from Thermotoga maritima in Caldicellulosiruptor bescii improves the phosphorolytic pathway and results in a dramatic increase in cellulolytic activity. Appl. Environ. Microbiol. 2017, 84, e02348-17. [CrossRef]

137. Kim, S.-K.; Chung, D.; Himmel, M.E.; Bomble, Y.J.; Westpheling, J. In vivo synergistic activity of a CAZyme cassette from Acidothermus cellulolyticus significantly improves the cellulolytic activity of the C. bescii exoproteome. Biotechnol. Bioeng. 2017, 114, 2474-2480. [CrossRef]

138. Kim, S.K.; Chung, D.; Himmel, M.E.; Bomble, Y.J.; Westpheling, J. Heterologous co-expression of two -glucanases and a cellobiose phosphorylase resulted in a significant increase in the cellulolytic activity of the Caldicellulosiruptor bescii exoproteome. J. Ind. Microbiol. Biotechnol. 2019, 46, 687-695. [CrossRef]

139. Kalbarczyk, K.Z.; Mazeau, E.J.; Rapp, K.M.; Marchand, N.; Koffas, M.A.G.; Collins, C.H. Engineering Bacillus megaterium strains to secrete cellulases for synergistic cellulose degradation in a microbial community. ACS Syn. Biol. 2018, 7, 2413-2422. [CrossRef]

140. Wu, L.; Xu, C.; Li, S.; Liang, J.; Xu, H.; Xu, Z. Efficient production of lactulose from whey powder by cellobiose 2-epimerase in an enzymatic membrane reactor. Bioresour. Technol. 2017, 233, 305-312. [CrossRef]

141. Zheng, T.Y.; Cui, J.X.; Bae, H.R.; Lynd, L.R.; Olson, D.G. Expression of adhA from different organisms in Clostridium thermocellum. Biotechnol. Biofuels 2017, 10, 5. [CrossRef] [PubMed]

142. Basen, M.; Sun, J.S.; Adams, M.W.W. Engineering a hyperthermophilic archaeon for temperature-dependent product formation. MBio 2012, 3, 8. [CrossRef] [PubMed]

143. Williams-Rhaesa, A.M.; Awuku, N.K.; Lipscomb, G.L.; Poole, F.L.; Rubinstein, G.M.; Conway, J.M.; Kelly, R.M.; Adams, M.W.W. Native xylose-inducible promoter expands the genetic tools for the biomass-degrading, extremely thermophilic bacterium Caldicellulosiruptor bescii. Extremophiles 2018, 22, 629-638. [CrossRef] [PubMed]

144. Sander, K.; Chung, D.; Hyatt, D.; Westpheling, J.; Klingeman, D.M.; Rodriguez, M.; Engle, N.L.; Tschaplinski, T.J.; Davison, B.H.; Brown, S.D. Rex in Caldicellulosiruptor bescii: Novel regulon members and its 
effect on the production of ethanol and overflow metabolites. MicrobiologyOpen 2018, 8, e00639. [CrossRef] [PubMed]

145. Bing, W.; Sun, H.J.; Wang, F.M.; Song, Y.Q.; Ren, J.S. Hydrogen-producing hyperthermophilic bacteria synthesized size-controllable fine gold nanoparticles with excellence for eradicating biofilm and antibacterial applications. J. Mat. Chem. B 2018, 6, 4602-4609. [CrossRef]

146. Shen, N.; Xia, X.-Y.; Chen, Y.; Zheng, H.; Zhong, Y.-C.; Zeng, R.J. Palladium nanoparticles produced and dispersed by Caldicellulosiruptor saccharolyticus enhance the degradation of contaminants in water. RSC Adv. 2015, 5, 15559-15565. [CrossRef]

147. Bai, Y.-N.; Lu, Y.-Z.; Shen, N.; Lau, T.-C.; Zeng, R.J. Investigation of Cr(VI) reduction potential and mechanism by Caldicellulosiruptor saccharolyticus under glucose fermentation condition. J. Hazard. Mater. 2018, 344, 585-592. [CrossRef]

(C) 2020 by the author. Licensee MDPI, Basel, Switzerland. This article is an open access article distributed under the terms and conditions of the Creative Commons Attribution (CC BY) license (http://creativecommons.org/licenses/by/4.0/). 